\title{
RMetS
}

\section{In situ aerosol measurements taken during the 2007 COPS field campaign at the Hornisgrinde ground site}

\author{
H. M. Jones, ${ }^{\star}$ J. Crosier, A. Russell, M. J. Flynn, M. Irwin, T. W. Choularton, H. Coe \\ and G. McFiggans \\ Centre for Atmospheric Science, SEAES, University of Manchester, UK \\ ${ }^{*}$ Correspondence to: H. M. Jones, University of Manchester, SEAES, Williamson Building, Oxford Road, Manchester, \\ M13 9PL, UK. E-mail: hazel.jones@manchester.ac.uk
}

The Convective and Orographically-induced Precipitation Study (COPS) campaign was conducted during the summer of 2007. A suite of instruments housed at the top of the Hornisgrinde Mountain $(1156 \mathrm{~m})$ in the Black Forest region of south-west Germany provided datasets that allow an investigation into the physical, chemical and hygroscopic properties of the aerosol particles sampled during COPS. Organic mass loadings were found to dominate the aerosol composition for the majority of the project, exceeding $8 \mu \mathrm{g} \mathrm{m}^{-3}$ during a period of high pressure, high temperature, and low wind speed. The ratio of organic:sulphate sub-micron mass concentration exceeds 10:1 during the same time period. Back trajectories show air from this time-frame passing slowly over the local forest and not passing over any local anthropogenic sources. Occasional peaks in nitrate mass loadings were associated with changes in the typical wind direction from south-westerly to north-westerly where air had passed over the Stuttgart region. Size distribution data shows a dominant accumulation-mode when the measurement site was free from precipitation events. A sharp increase in ultrafine particle number concentration was seen during most days commencing around noon. The apparent growth of these particles is associated with an increase in organic mass loading, suggesting condensational growth. For the most part, with the exception of the high pressure period, the aerosol properties recorded during COPS were comparable to previous studies of continental aerosol properties. Copyright (C) 2010 Royal Meteorological Society

Key Words: aerosol physical properties; composition; hygroscopicity; aerosol-cloud interaction

Received 21 April 2010; Revised 12 October 2010; Accepted 13 October 2010; Published online in Wiley Online Library

Citation: Jones HM, Crosier J, Russell A, Flynn MJ, Irwin M, Choularton TW, Coe H, McFiggans G. 2010. In situ aerosol measurements taken during the 2007 COPS field campaign at the Hornisgrinde ground site. Q. J. R. Meteorol. Soc. DOI:10.1002/qj.727

\section{Introduction}

The number, size and composition of the local aerosol particle population are important in determining the cloud droplet number and size and consequently, the optical properties and precipitation behaviour of the cloud. The population of cloud condensation nuclei (CCN) entering cloud base is important in determining the extent and onset of warm rain produced by collision coalescence. Khain and Pokrovsky (2004) suggested that the cloud response to increased $\mathrm{CCN}$ may be ambiguous and nonlinear, and depend on the atmospheric stability, initial aerosol distribution and humidity. Several satellite-based investigations indicate a possible link between input aerosol 
particles, microphysical evolution of convective clouds and resulting precipitation (e.g. Ramanathan et al., 2001). While the aerosol indirect effect on warm clouds is recognised as having the largest quantified uncertainty in climate forcing, the climatic effect of aerosol particles on mixed-phase/ice clouds is largely unknown (Denman et al., 2007).

Convective cloud formation, particularly where orography plays a role, is important because of the potential for intense precipitation. Convection plays an important part in many flood situations, especially flash floods. Unfortunately current forecast models are unable to accurately predict heavy convective showers and thunderstorms over orography. This is in part due to a poor understanding of the thermally driven orographic flow of moisture and aerosols that enter the storms, and also the details of the aerosols, cloud microphysics and cloud dynamics, all of which have a controlling factor in the resultant precipitation (e.g. Lynn et al., 2007; Muhlbauer and Lohmann, 2008).

The Convective and Orographically-induced Precipitation Study (COPS) field project was carried out during the summer months of 2007 over the northern Black Forest region of south-western Germany (Figure 1). For an overview of the experiment and a summary of the key findings the reader is referred to Wulfmeyer et al. (2008). Intensive observation periods (IOPs) were designated for days where convection was expected in the COPS region (Table I). IOPs during the time-frame of the ground-based aerosol measurements are indicated on Figure 2.

Previous work in the COPS region has shown that the boundary layer is characterized by channelling effects in the Rhine Valley (e.g. Kalthoff and Vogel, 1992), thermally induced circulations above the slopes and in the valleys of the Black Forest (e.g. Hauf and Witte, 1985) and strong wind speed over the top and flow separation in the lee of the Hornisgrinde mountains (e.g. Kossmann, 1992). Others (e.g. Vögtlin et al., 1996; Kossmann et al., 1999) have shown updraughts from the valley by measuring trace gases at key points up the slope of the valley towards the Hornisgrinde Mountain site. It was found that when the boundary layer top in the valley was well below the mountaintop, then upslope winds were able to act as an effective transport process of the valley air pollutants to the upper levels (Whiteman and McKee, 1978). The presence of such elevated pollution layers are important, especially during high pressure weather periods, as subsidence can transport these layers to lower levels on subsequent days (Millán et al., 1997), thus increasing aerosol concentrations in the boundary layer.

Observed physical and chemical aerosol properties vary greatly for different locations and times (e.g. O'Dowd et al., 2004; Putaud et al., 2004, 2010). The finemode aerosol (diameter $<1$ micron) in the background planetary boundary layer is generally composed of secondary components such as sulphate, nitrate, ammonium and organic compounds in addition to primary components such as elemental carbon and some types of organic carbon (e.g. Seinfeld and Pandis, 1998). A large number of studies in the Northern Hemisphere using an on-line Aerodyne aerosol mass spectrometer (AMS: see Canagaratna et al. (2007) for details) have shown a major component of the submicron aerosol composition is organic matter (OM) (Zhang et al., 2007). European studies have also shown a significant contribution of ammonium nitrate to the sub-micron particulate, particularly during highly polluted conditions, where $\mathrm{OM}$ and ammonium nitrate contributed $20-50 \%$ each to the non-refractory mass (Putaud et al., 2004; Morgan et al., 2009). OM concentrations were found to be typically 1.5-2.0 times greater than that of sulphate, where sulphate contributed $10-30 \%$ of the non-refractory particulate mass. Sub-micron mass loadings from AMS measurements exceeded $15 \mu \mathrm{g} \mathrm{m}^{-3}$ downwind of major source regions where significant amounts of anthropogenically influenced aerosol built up (Morgan et al., 2009). Information on the broad chemical characteristics of the organics can be obtained by inspecting the mass spectra once inorganic contributions have been removed (Lanz et al., 2007; Ulbrich et al., 2009; Allan et al., 2010).

Organic compounds represent an important yet poorly understood aerosol component compared with inorganic compounds such as nitrate and sulphate (Jacobson et al., 2000). Organic aerosol particles are composed of a highly complex mixture of many organic species (e.g. Hamilton et al., 2004). Organic carbon is found in primary carbonaceous particles and also in particles having originated from gas-to-particle conversion processes: secondary organic aerosol (SOA), where aerosol is formed by chemical transformation and condensation of volatile and semi-volatile species (Jimenez et al., 2009). While there is evidence from previous field studies performed in urban areas that organic material is likely anthropogenic in origin (e.g. Aiken et al., 2009; Hoyle et al., 2010), there is ample evidence from field studies performed in background areas to suggest that organic components may be biogenic in nature, having their origins in forested regions (e.g. Hämeri et al., 2001; Kulmala et al., 2004b).

The influence of the organic fraction has been postulated to be important via the suppression of surface tension (e.g. Facchini et al., 1999, 2000; Kiss et al., 2005) and the change in the Raoult effect. More recently, coupling of the Kelvin and Raoult terms by partitioning of surface active organic molecules from the bulk of an activating particle to the surface layer has been postulated to largely offset surface tension effects of organic compounds (Sorjamaa et al., 2004; Kokkola et al., 2006; Sorjamaa and Laaksonen, 2006; Topping et al., 2007; Good et al., 2010a). Whilst investigated and demonstrated convincingly in the laboratory (e.g. Hanford et al., 2008; Prisle et al., 2008), field assessment of any of these effects is very limited.

Processes governing the formation and growth of atmospheric aerosol particles are important, and require quantification if they are to be considered and included in regional and global climate models (Spracklen et al., 2006). Under anthropogenically influenced conditions, primary emissions control the particle number (e.g. Raes et al., 2000; Mönkkönen et al., 2005) whereas away from pollution plumes, nucleation may determine the ambient number concentration of small $(<100 \mathrm{~nm})$ particles (e.g. Kulmala et al., 2004a; Allan et al., 2006; Kazil et al., 2010). The study of freshly nucleated particles is difficult due to instrument limitations regarding measurements of very small particles $<2.5 \mathrm{~nm}$. Composition of smaller particles is also limited, due to the small amount of mass involved. Newly formed particles are particularly susceptible to changes due to physical and chemical processes e.g. dilution, condensation, coagulation and chemical reactions (e.g. Seinfeld and Pandis, 1998). Particles must grow to significant sizes if they are to affect the optical properties of the atmosphere and clouds (e.g. Kirkevåg and Iversen, 2002; Forster et al., 2007). Global 


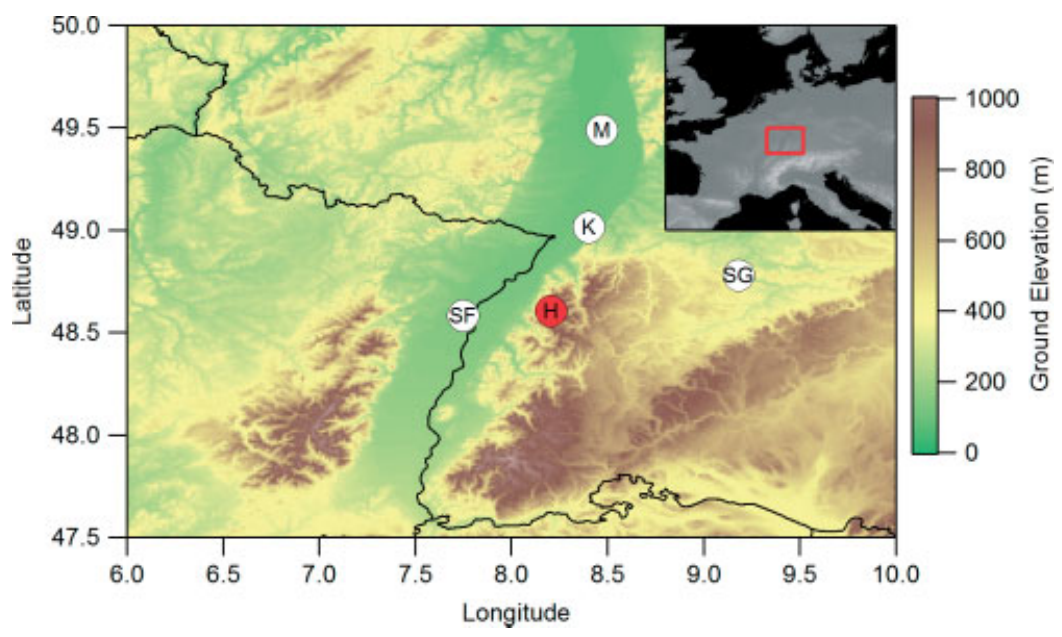

Figure 1. Map of the COPS area. Hornisgrinde Mountain ground site is marked by an ' $H$ '. ' $K$ ' shows the position of Karlsruhe, Germany. ' $M$ ' shows the position of Mannheim, Germany. 'SG' shows the position of Stuttgart, Germany. 'SF' shows the position of Strasbourg, France.

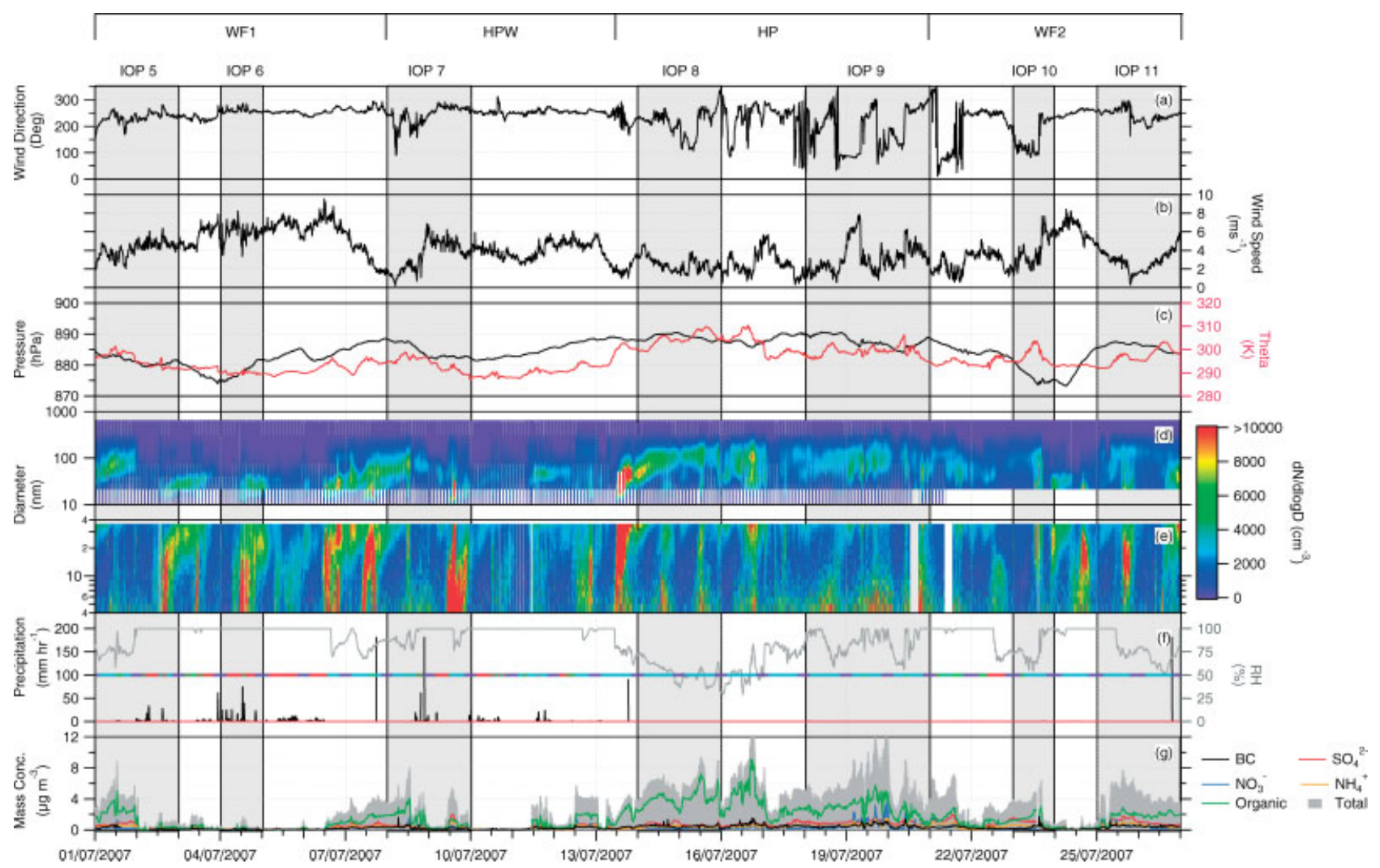

Figure 2. Time series from 0000 UTC 1 July 2007 to 0000 UTC 27 July 2007 showing (a) wind direction (degrees), from the AWS, (b) wind speed (m/s), from the AWS, (c) potential temperature (K), red line, and pressure ( $\mathrm{hPa}$ ), black line, from the AWS, (d) L-DMPS size distribution, (e) N-DMPS size distribution, (f) relative humidity (\%), grey line, from the AWS; precipitation rate ( $\mathrm{mm} /$ day), from the disdrometer, black line; precipitation (mm), from the rain-gauge at Raumunzach, red line; camera data (purple $=$ darkness, cyan $=$ blue sky visible, green $=$ complete cloud cover, red $=$ site above cloud base), (g) AMS mass concentration $\left(\mu \mathrm{g} \mathrm{m}^{-3}\right)$ for nitrate, sulphate, ammonium and organics; MAAP black carbon mass concentration $\left(\mu \mathrm{g} \mathrm{m}^{-3}\right)$ along with total mass $\left(\mu \mathrm{g} \mathrm{m}^{-3}\right)$. Shaded regions indicate designated COPS IOPS, from IOP5 to IOP11, where IOPs longer than a day are subcategorised into e.g. IOP5a, IOP5b, for each day of the period.

CCN concentrations have been computed to be dominated by the secondary aerosol formed by nucleation (Merikanto et al., 2009).

An investigation into ultrafine particle formation and growth at Hyytiälä, Finland (Scandinavian forest region) pointed to local biogenic volatile organic compounds (VOCs) and oxidation products contributing to the growth of particles initially formed by the nucleation of sulphuric acid with water and/or ammonia (Kulmala et al., 2000). Work by Zhang et al. (2004) carried out in Pittsburgh,
USA showed that the composition of ultrafine particles at the earliest stages of growth was predominantly sulphuric acid. During the more advanced stages of growth, results showed an increase in ammonium sulphate, with organic matter recorded when aerosol particles reached larger sizes (30-60 nm diameter). Measurements from Atlanta, USA concluded that ammonium sulphate was the principal condensing species (Smith et al., 2005).

Atmospheric aerosols are typically hygroscopic such that water becomes the dominant component at modest to high 
Table I. Back-trajectory data

\begin{tabular}{lccl}
\hline Date(s) & IOP & Wind & Description \\
\hline $1-3$ July & IOP5 & SW & Air gradually coming from further away over this period \\
$4-7$ July & IOP6 & W & Passing over the southern tip of England \\
8 July & IOP7a & WW & Slow winds i.e. short BT \\
9 July & IOP7b & NW & Air masses originated from closer to the site \\
$10-12$ July & - & W & Air coming over northern France \\
13 July & - & W & Air approaching from over France \\
14 July & IOP8a & - & Very localised \\
15 July & IOP8b & SW & - \\
$16-17$ July & - & W & Slow winds i.e. short BT \\
18 July & IOP9a & NW & Slow winds i.e. short BT \\
19 July & IOP9b & SW & - \\
20 July & IOP9c & SW & BT passing over France \\
$21-22$ July & - & SW & BT passing over northern Spain \\
23 July & IOP10 & NW & BT passing over the North Sea \\
24 July & - & NW & BT passing over central England \\
25 July & IOP11a & SW & Slow BT passing over France \\
26 July & IOP11b &
\end{tabular}

Includes general direction of incoming wind to the measurement site and the location where the air mass passed 24 hours previous to its arrival at the site.

relative humidity $(\mathrm{RH})$. This uptake of water affects the direct and indirect climate effects of particles. The ability of a particle to absorb water is dependent on its composition (e.g. McFiggans et al., 2006). Particles that are more hygroscopic also make more efficient cloud condensation nuclei (Weingartner et al., 1997); as such, the ageing of particles also influences the aerosol indirect effect. If aerosol particles are internally mixed, it is the inorganic:organic ratio that determines the overall hygroscopicity of the aerosol particles (McFiggans et al., 2005). Ageing of an aerosol population could decrease the inorganic to organic ratio (condensation of organic vapours) or increase it (condensation of inorganic vapours) depending on the nature of the vapours available; either of these effects would affect the overall hygroscopicity and CCN activity (e.g. Rudich et al., 2007).

The hygroscopic growth factor is defined as $G F_{\mathrm{D}, 90 \%}=$ $D_{90 \%} / D_{0}$, where $D_{90 \%}$ is the diameter at $90 \% \mathrm{RH}$ and $D_{0}$ is the dry size. Multiple growth factor modes may exist for any given aerosol population of variable composition, dependent on distance from source. Previous studies have revealed that fresh aerosol at source (e.g. vehicle exhaust) exhibits a $G F_{90}$ around 1 (hygrophobic). These aerosol particles are typically smaller particles that are composed of primarily carbonaceous material. Urban aerosol growth factor distributions typically exhibit growth factors between 1.1 and 1.3 , though on occasion can also have a secondary peak in the hygrophobic range. This slightly hygroscopic mode generally consists of small particles with a high organic mass fraction. This mode has been attributed to freshly emitted particles by a number of urban studies (e.g. Cocker et al., 2001; Väkevä et al., 2002). Urban environments typically show an externally mixed aerosol, displaying the two separate modes (Swietlicki et al., 1999). Measurements of aged background aerosol show aerosol exhibiting $G F_{90}$ of $1.4-1.8$, sometimes referred to as the more-hygroscopic mode and observed in varying environments, e.g. urban sites (Cocker et al., 2001), continental background sites (Zhou et al., 2002), and marine sites (Maßling et al.,
2003). These aerosol particles typically consist of a higher inorganic mass fraction with a secondary organic aerosol component (e.g. McMurry et al., 1996). It is important to know the hygroscopic behaviour of aerosol particles as this will determine how they interact with clouds (King et al., 2009; Petters et al., 2009a).

This paper presents measurements of the physical and chemical properties of aerosol during July 2007 as part of COPS. Aerosol measurements from a suite of instruments at a ground site situated at the top of the Hornisgrinde Mountain within the Black Forest region are used here to identify the physical and chemical attributes of aerosol particles in the COPS region.

\section{Methodology}

The Hornisgrinde ground site is located at $48.604^{\circ} \mathrm{N}$ and $8.204^{\circ} \mathrm{E}, 1156 \mathrm{~m}$ above sea level (ASL). This is the highest elevation in the northern Black Forest region of Germany, with the Murg Valley situated to the north, Kinzig Valley to the south and Rhine Valley to the west (Figure 1). This hilltop location is an ideal site to represent the inflow to the convection developing in the region. A suite of instruments was housed inside a temperature-controlled container located in an open space with the only traffic being those cars visiting the science site. The Rhine Valley is $\sim 35 \mathrm{~km}$ wide near the ground site, with inhomogeneous land use (industrialised and agricultural areas, settlements and deciduous forest); in contrast, the Black Forest is mostly pines and firs with some open areas due to deforestation and storm damage.

Local aerosol was sampled through a common inlet $3 \mathrm{~m}$ above the ground through a cyclone impactor with a $4 \mu \mathrm{m}$ cut-off. During periods when cloud was present at the site, the instruments would only be able to sample particles below $4 \mu \mathrm{m}$ in size, and therefore would likely represent the inactivated or evaporating fraction of the particles. Aerosol composition was measured on-line using 
an Aerodyne High-Resolution Time-of-Flight Aerosol Mass Spectrometer (HR-ToF-AMS: DeCarlo et al., 2008) which provided mass loadings of organic, nitrate, sulphate and ammonium sub-micron aerosol $(40-700 \mathrm{~nm})$, with a MultiAngle Absorption Photometer (MAAP) providing a measure of the total black carbon (BC) loading by converting the measured absorption to mass, as described by Petzold et al. (2002). A mass specific absorption of $6.67 \mathrm{~m}^{2} \mathrm{~g}^{-1}$ is used to derive the BC concentration. Details of the operation of the AMS can be found in Canagaratna et al. (2007). The data were analyzed following Allan et al. (2003, 2004) and Jimenez et al. (2003). All masses are reported at ambient pressure and temperature. Size distribution data of the local aerosol were provided by a Differential Mobility Particle Sizer (DMPS) in the range 5-650 nm dry mobility diameter. The instrument comprised two Vienna-type Differential Mobility Analyzers (DMAs) that stepped over size ranges of 5-30 nm (N-DMPS) and 20-650 nm (L-DMPS) (Williams et al., 2007). An optical particle counter (GRIMM-1.108 OPC) measured particles in the scattering diameter range $0.3-20 \mu \mathrm{m}$.

A Cloud Condensation Nucleus counter $(\mathrm{CCN}$, Droplet Measurement Technologies: Roberts and Nenes, 2005) was used to measure the activated particle number concentration of the local aerosol across the DMPS size distribution at five different supersaturation values $(0.11,0.17,0.32,0.5$ and 0.8 ). This allows an activated fraction of the total aerosol to be calculated by dividing it by the total number concentration given by a Condensation Particle Counter (CPC, TSI 3010) which measures aerosol particle total concentration in the size range 10-1000 nm. A Hygroscopic Tandem Differential Mobility Analyzer (HTDMA: Cubison et al., 2005) gave the hygroscopic growth factor probability distribution $(G F)$ at a set $\mathrm{RH}$ level $(86 \%)$ for seven dry particle diameters $(26$, $43,85,127,169,211$ and $254 \mathrm{~nm}$ ). The hygroscopic growth factor is defined as $G F_{\mathrm{D}, 86 \%}=D_{86 \%} / D_{0}$, where $D_{86 \%}$ is the diameter at $86 \% \mathrm{RH}$ and $D_{0}$ is the dry size. HTDMA and CCNc set-up, calibration details and in-depth analysis for the COPS project can be found in Irwin et al. (2010). An Automatic Weather Station (AWS), provided by the University of Innsbruck, recorded pressure $(45 \mathrm{~cm}$ above ground level (AGL)), temperature (187 cm AGL), relative humidity (187 cm AGL), and wind speed and direction $(300 \mathrm{~cm}$ AGL) at one-minute intervals.

The ground-based aerosol measurements commenced on 26 June 2007, and ended 27 July 2007, with the exception of the CCNc and HTDMA measurements which were completed on 20 July 2007. Datasets for the above instruments are mostly continuous with breaks in data due mainly to set-up and calibration, but occasionally due to low number concentrations when sampling within clouds. For this paper, the aerosol measurement period is defined as 0000 UTC 1 July 2007 to 0000 UTC 27 July 2007. The L-DMPS operated in two different modes, alternating every hour. One mode was optimized to provide the CCNc with mono-disperse ambient aerosol at sizes of interest for greater periods of time, increasing signal to noise. The other mode of operation was that used for standard L-DMPS operation (scanning from $\sim 23 \mathrm{~nm}$ to $650 \mathrm{~nm}$ ) when the $\mathrm{CCNc}$ was sampling poly-disperse ambient aerosol. Both modes had a 10-minute scan time. The data from both of these modes were merged after processing to provide a continuous measurement of the aerosol size distribution, with the data subsequently re-binned ( 34 bins equally spaced in log-space from 10 to $750 \mathrm{~nm}$ ) to provide continuity between the two modes of operation.

In addition to the above measurements, a back-trajectory analysis of the origins of the air masses arriving at the Hornisgrinde Mountain site was carried out; details are given in the results section. The back trajectories were provided by the British Atmospheric Data Centre (BADC) using 1.125 degree resolution wind-field archive data from the European Centre for Medium-range Weather Forecasts (ECMWF).

\section{Results}

\subsection{Meteorological overview}

The weather conditions during the UK-COPS period have been examined via the construction of an animation showing the key meteorological factors. This animation is available in the on-line Supplementary Material provided with this paper. It shows the following products: the geopotential height of the $850 \mathrm{hPa}$ surface in metres (main plot); Met Office NIMROD radar rainfall rate (stippling over the United Kingdom, France, the Benelux nations and Germany), where lighter stipple shading indicates higher rainfall rate; a cluster of 24-hour back trajectories (red and white tracks) initiated above the Hornisgrinde location $+250 \mathrm{~m}$ north, south, east and west from a height of $850 \mathrm{hPa} \pm 10 \mathrm{hPa}$ at 1200 UTC each day; wind speed and direction from an AWS located at the top of the Hornisgrinde (top left, the four rings relate to winds of 2, 4, 6 and $8 \mathrm{~m} \mathrm{~s}^{-1}$ ); and the aerosol mass concentration and size distribution data (bottom left, see Figure 2 for more details).

For the early part of the UK-COPS period (1-8 July 2007), a large region of low pressure and high pressure were situated to the north and to the south of the COPS region respectively. The COPS region was therefore characterized by relatively strong westerly or west-south-westerly winds and regular frontal precipitation events. Between 3 and 5 July, the site was above cloud base for most of this time, with conditions clearing around noon on 6 July. COPS IOP 5 (1-2 July 2007) and IOP 6 (4 July 2007) occurred in this period. Table I shows information regarding the back-trajectory analysis (trajectory direction and origin of 1-day-old air) for this period and the following period.

During 8-13 July 2007, the high pressure region pushed northwards, though only to the west of the COPS region, which resulted in a slowing of the westerlies during this period. Precipitation was still seen on most days, though notably not on 7 or 8 July 2007. Clouds were seen frequently over the site during this period, with the site above cloud base during the mornings of 9, 10 and 12 July. COPS IOP 7 (8-9 July 2007; see Russell et al. (2010), for an in-depth investigation) occurred in this period.

The high pressure region eventually developed into a ridge that was aligned over the COPS region for 14-17 July 2007. In this period, the winds were light and changeable with little precipitation or cloud cover observed in the COPS region. COPS IOP 8 (14-15 July 2007) occurred in this period. By 18 July 2007 the ridge had moved further to the east and the winds picked up again although the conditions on 19-20 July 2007 were similar to the 14-17 July 2007 phase when a smaller ridge moved over the COPS region - this coincided with COPS IOP 9 (18-20 July 2007). 
From 21 to 26 July 2007 the situation was quite similar to that during the first period, with a high situated to the south and a low positioned to the north, but the winds were generally lighter. Extensive cloud covered the region during 21 and 22 July, and again for 24 July. COPS IOP 10 (23 July 2007) and IOP 11 (25-26 July 2007) occurred in this final phase.

For the purposes of this paper, and the following aerosol overview, the period 00001 July 2007-0000 8 July 2007 shall be referred to as Westerly Flow period 1 (WF1), 0000 8 July 2007-1200 13 July 2007 as High Pressure to the West (HPW), 120013 July 2007-0000 21 July 2007 as High Pressure period (HP), 000021 July 2007-0000 27 July 2007 as Westerly Flow period 2 (WF2).

\subsection{Aerosol overview}

During WF1 and WF2 when advective conditions were experienced across the COPS region, widespread cloud cover and precipitation at the measurement site led to low aerosol mass (Figure 2(g)). At times when aerosol is not removed by cloud processes, aerosol particles are found to consist of nitrate, sulphate, organic compounds, ammonium and black carbon. The major component to the mass loadings was typically organic matter, though during WF2 sulphate mass loadings increased such that sulphate was the major mass component around midnight of 23/24 July. Ammonium mass loadings at the Hornisgrinde site were consistently low for the COPS period. During WF2, the organic:sulphate ratio reached 3:1, whereas during WF1 it reached 4:1. During WF1, mass composition was $40-60 \%$ organic, $15-30 \%$ sulphate, $5-20 \%$ nitrate, $10-20 \%$ ammonium and 5-40\% black carbon material (Figure 3). Total measured mass ranged from $0 \mu \mathrm{g} \mathrm{m}^{-3}$ during within cloud periods, to up to $6 \mu \mathrm{g} \mathrm{m}^{-3}$ on 1 July. During the short breaks in cloudiness, the total measured sub-micron mass reaches $\sim 1 \mu \mathrm{g} \mathrm{m}^{-3}$. During WF2, mass composition is only slightly different: $30-60 \%$ organic, $10-40 \%$ sulphate, $5-30 \%$ nitrate, $5-20 \%$ ammonium and $5-30 \%$ black carbon by mass, with total mass loadings around $4 \mu \mathrm{g} \mathrm{m}^{-3}$. For both these periods, the peak diameter in the measured aerosol particle number size distribution was $<50 \mathrm{~nm}$, with the exception of 1 July (IOP5a), when peak aerosol size was in the accumulationmode size range. Additional number size distribution information can be seen in Figure 4, where the median, $25^{\text {th }}$ and $75^{\text {th }}$ percentile of the size distribution data from each of the designated meteorological periods are shown. The WF1 and WF2 number size distribution plots show the constant presence of an Aitken mode $(\sim 40 \mathrm{~nm})$ for both of these periods, along with an accumulation-mode whose strength varies across the periods. It is worth remembering that the size distribution measurements sampled were from an inlet which only sampled interstitial particles during periods of cloud. The reduced accumulation-mode number of the $25^{\text {th }}$ percentile shows the presence of cloud activating the bulk of accumulation-mode particles. The similarity between the median and $75^{\text {th }}$ percentile accumulation-mode number distributions during WF1 indicates that the site was enveloped in cloud less than $50 \%$ of the time, a finding that is supported by the weather sensor measurements. Clouds were frequently present above the site, particularly during the WF1 period, and as such a strong Hoppel dip (Hoppel et al., 1994) can be seen for this case in both the median and $75^{\text {th }}$ percentile size distributions due to the resulting cloud processing.

At the start of the HPW period, organic matter dominated the aerosol composition before precipitation reduced the aerosol population at the measurement site. Mass composition was $40-60 \%$ organic, $10-30 \%$ sulphate, $5-20 \%$ nitrate, $10-20 \%$ ammonium and $10-15 \%$ black carbon. Average total mass loading was $\sim 2 \mu \mathrm{g} \mathrm{m}^{-3}$ for the HPW period. During IOP7b, aerosol number concentration increased during a break in precipitation with sulphate mass loading dominating the composition (reaching $2 \mu \mathrm{g} \mathrm{m}^{-3}$ ). Comparison of the L-DMPS time series with the AMS mass loading time series showed that reductions in the accumulation-mode were strongly linked to reductions in the organic mass loading signal; this is particularly evident during the HP period. There is a gap in the AMS and DMPS data for 10 July and the morning of 11 July, after which organic mass was again the dominant species. Due to the frequent precipitation events during this period, aerosol number size distribution data show aerosol particles were typically $<50 \mathrm{~nm}$ in diameter. On 13 July there was a transition to the HP period, when the appearance of ultrafine (<10 nm diameter) aerosol particles was observed along with apparent growth into larger sizes, and an increase in measured peak aerosol size was seen overnight. Aerosol mass increased around noon, with organic mass dominating and the organic:sulphate ratio exceeded 10:1 at peak mass (Figure 3).

The HP period featured a clear dominance of organic material, with typical composition values of $50-80 \%$ organic, $10-25 \%$ sulphate, $2-30 \%$ nitrate, $2-15 \%$ ammonium and $5-20 \%$ black carbon. Total mass exceeds $3 \mu \mathrm{g} \mathrm{m}^{-3}$ at peak daily values for each day in this period. The highest mass loadings for the COPS campaign were measured on 16 July, with organic mass loading exceeding $9 \mu \mathrm{g} \mathrm{m}^{-3}$, and total measured mass loadings exceeding $10 \mu \mathrm{g} \mathrm{m}^{-3}$. The organic to sulphate mass ratio also exceeded 10:1 on 15 (IOP8b) and 16 July. Peaks in the nitrate mass loading (reaching $3 \mu \mathrm{g} \mathrm{m}^{-3}$ ) can be seen on 19 July (IOP9b), when back trajectories show air passed over a source of pollution (urban areas surrounding Stuttgart) less than a day before to the northwest of the measurement site. Number size distribution data during this period typically peaked at sizes $>100 \mathrm{~nm}$, whereas on the few days with no precipitation during WF1 and HPW the peak was closer to $50 \mathrm{~nm}$. The size distribution plot for the HP period (Figure 4) shows a broad and flat distribution. Little cloud was present during the period and winds were light. Under such conditions the predominant aerosol process is condensational growth, and accumulation-mode aerosol lifetimes are long. It is also noted that there is little variation between the $25^{\text {th }}$ and $75^{\text {th }}$ percentile indicating a similar aerosol population is present throughout this period. Comparison of this plot with the other meteorological periods shows that during the HP period, a larger number of aerosol particles were present at the Hornisgrinde site, particularly at accumulation-mode sizes, consistent with the enhanced aerosol mass observed with the AMS (Figure 2(g)).

Growth factor data from the HTDMA are available for the periods designated WF1, HPW and HP. Figure 5 shows box and whisker plots for the data in each period, also see Figure 1 in Irwin et al. (2010) for a breakdown of this data. Small aerosol (26-43 nm) detected during WF1, HPW and HP typically showed low growth factors, peaking at 

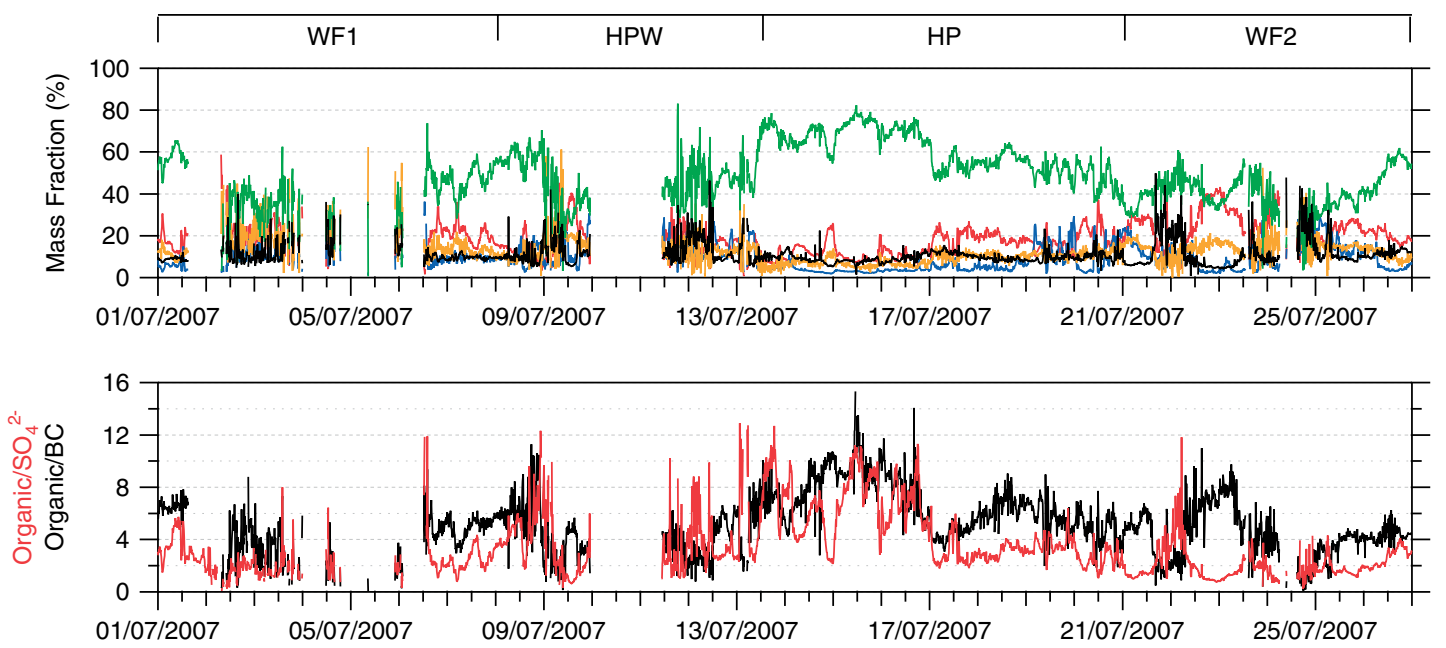

Figure 3. (a) Percentage mass composition from the AMS and MAAP instruments (green $=$ organic, red $=$ sulphate, blue $=$ nitrate, yellow $=$ ammonium, black = black carbon); some values not valid for when low mass concentrations were measured. (b) Organic:sulphate mass concentration ratio (red) and organic:black carbon mass concentration ratio (black).
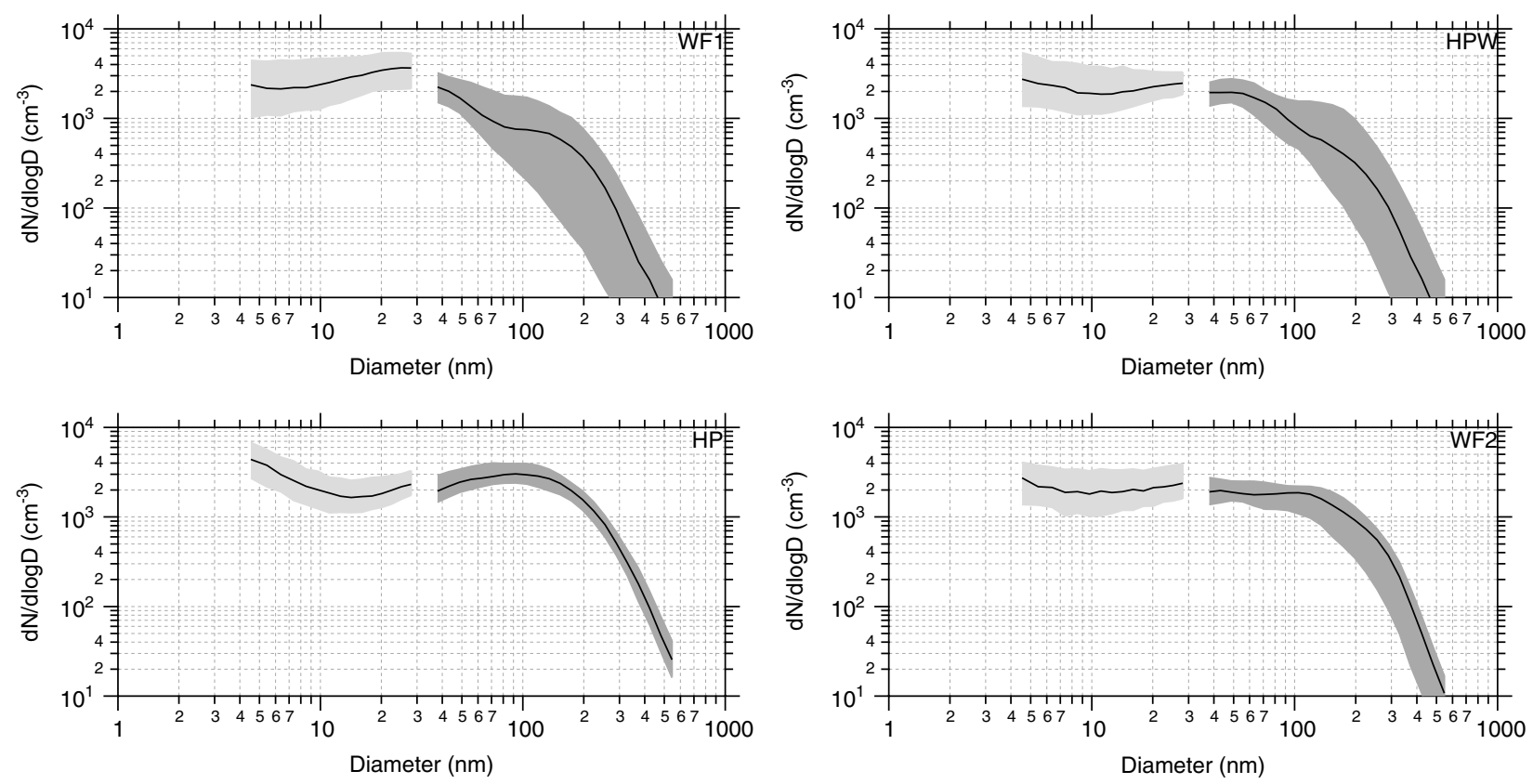

Figure 4. DMPS number size distribution information (N-DMPS and L-DMPS) for the four designated meteorological periods (WF1, HPW, HP and WF2). Solid black line indicates the median size distribution for each period; the extremities of the grey shaded area indicate the 25 th and 75 th percentile size distribution plots.

values of 1.1. For WF1 and HPW, 85-127 nm particles were a predominantly external mixture with both a lesshygroscopic mode (1.0) and more-hygroscopic mode (1.3). Particles of size $254 \mathrm{~nm}$ were internally mixed aerosol with a mean growth factor of 1.4. Increased external mixing was observed during HPW compared to WF1, particularly at the larger sizes.

For some of WF1, the number of larger-sized particles was below the detection limit: they were removed by cloud processing, particularly on 4 and 5 July. Data from 3 to 5 July are likely to represent inactivated aerosol particles or the residue of evaporated small cloud droplets. During within cloud periods, the dominant peak in the growth factor probability distribution was at smaller values $(\sim 1.0)$, whilst in out of cloud periods the dominant peak was at the larger values $(\sim 1.3)$. On 6 to 7 July the growth factor peak can be seen to shift to larger values, reaching a peak at 1.4 for particles of size $254 \mathrm{~nm}$.

Data solely from IOP7b (9 July 2007) during the HPW period show a clear bimodal growth factor distribution, with peaks centred at 1.0 and 1.4 evident at sizes $127 \mathrm{~nm}$ and greater; a similar result is seen for 12 July. Data for 10 and 11 July are not available due to calibration. Data from 13 July show a change in peak growth factor from morning until afternoon when the high concentrations of ultrafine particles were detected and organic mass loading increased, whereas growth factors at the larger sizes decreased to 1.2 in the afternoon and from 1.3 in the morning.

HTDMA data for the HP period appear to show internally mixed aerosol particles at all sizes, with the smallest sizes showing mean growth factors peaking at 1.1, increasing to 1.3 at the largest sizes. On 19 July (IOP9b) there was a slightly higher mean growth factor of 1.15 at dry sizes 
(a) WP1

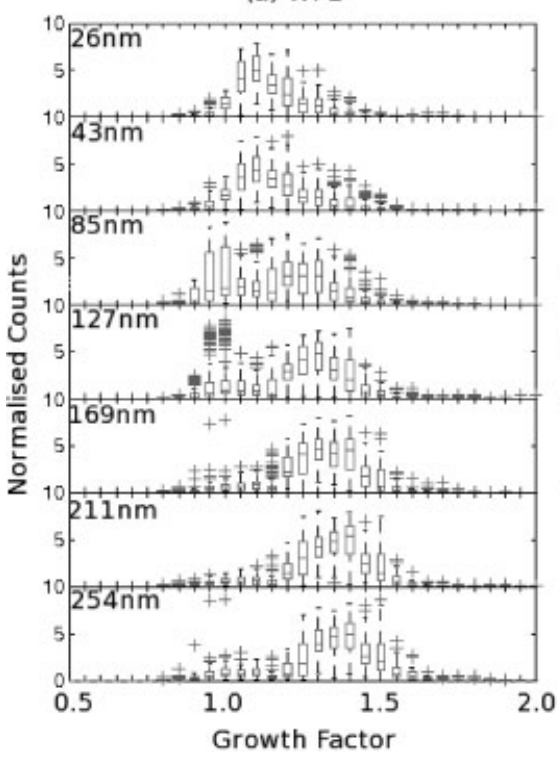

(b) HPW

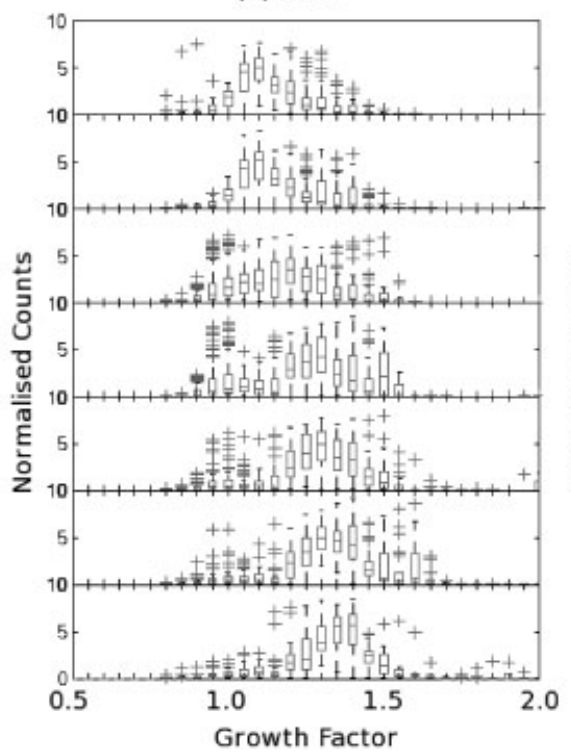

(c) HP

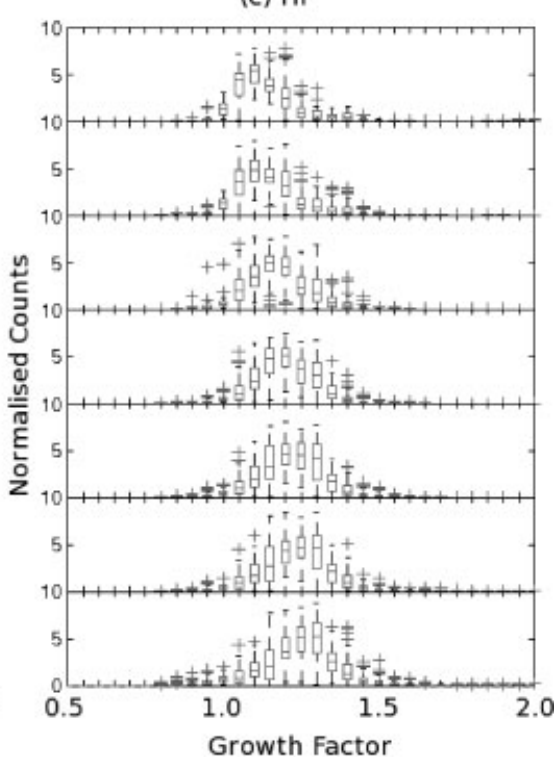

Figure 5. Box and whisker plots showing the retrieved growth factor distribution for (a) WF1 period, (b) HPW period, and (c) HP period, for dry diameters $26,43,85,127,169,211$ and $254 \mathrm{~nm}$. The box-bound horizontal line shows the median value, the vertical extremities of the box represent the 25 th and 75 th percentile, the whiskers showing the 5 th and 95 th percentile, crosses represent outlier values.

Table II. Average $\kappa$ values from the CCNc and HTDMA over the COPS project (Irwin et al., 2010)

\begin{tabular}{lcc}
\hline Dry diameter $(\mathrm{CCN} / \mathrm{HTDMA})(\mathrm{nm})$ & $\kappa_{\mathrm{CCN}}$ & $\kappa_{\mathrm{HTDMA}}$ \\
\hline 26 & - & 0.13 \\
43 & 0.43 & 0.12 \\
85 & 0.31 & 0.13 \\
$121 / 127$ & 0.23 & 0.17 \\
$161 / 169$ & 0.17 & 0.2 \\
211 & - & 0.22 \\
\hline
\end{tabular}

of 26 and $43 \mathrm{~nm}$. There was little cloud over the site during the HP period and no occasion when the site was within cloud. It is difficult to parametrize hygroscopicity for the many organic species that exist or for complex, multi-component aerosol. Petters and Kreidenweis (2007) introduced the hygroscopicity parameter $\kappa$, which captures the contribution of the Raoult term to the hygroscopic growth. $\kappa$ describes the relationship between dry particle diameter and CCN activity. $\kappa$ values were derived from CCN and HTDMA data; see Table II, which reports average $\kappa$ values for the COPS project for each size measured. The reader is referred to Irwin et al. (2010) for a more detailed analysis of $\kappa$ values for COPS.

The CCN concentration time series is shown in Figure 6 for 13-16 July, chosen as it is representative of the spread of critical supersaturation and activated fraction across the entire campaign, shown in detail by Irwin et al. (2010). Concentrations were low until around noon on 13 July in correspondence to the low mass concentration measured by the AMS. HTDMA growth factor data shows a reduction in peak growth factor at sizes larger than $85 \mathrm{~nm}$ in the afternoon compared to the morning. The sharp increase in CCN concentrations seen on 13 July coincided with the sharp increase in ultrafine particles and organic mass loading. Comparison with the DMPS plots (Figure 2(d) and (e)) shows that during the afternoon of 13 July, all particles $>100 \mathrm{~nm}$ are activated, as are many particles less than this size. For a more detailed analysis of the measured hygroscopic properties of aerosol particles during the COPS project, the reader is referred to Irwin et al. (2010).

\subsection{Ultrafine particles}

The appearance of ultrafine particles occurred around noon on each day for the period shown in Figure 2(e), although the strength of the signal varied in intensity. The abrupt appearance of large numbers of ultrafine particles on 13 July, and their apparent growth to larger sizes, was associated with an increase in organic mass and an increase in organic:sulphate mass ratio. Around 0300 UTC 14 July 2007, the size distribution peak shifts to larger sizes; during this time the mass concentration of sulphate also increases.

During early July (3-5 July), the site was within cloud for the majority of the time, yet even under these conditions ultrafine particles were clearly observed. A cloud camera at the site revealed short periods of time on 3 and 4 July when clear sky was observed above the site, during which times the increase in small particles was observed. On 5 July, no such break in cloud was seen by the cloud camera (data every 5 minutes); however, cloud radar data at the site revealed reductions in cloud top height to $<150 \mathrm{~m}$ (minimum data range). These times of lower cloud top height coincided with the observed small increases (to no greater than $9 \mathrm{~cm}^{-3}$ ) in aerosol number at small sizes $(<30 \mathrm{~nm})$, with no subsequent detected growth into larger sizes. In contrast, the strongest event ( 9 July) saw total $\mathrm{N}$-DMPS concentration exceed $100000 \mathrm{~cm}^{-3}$ where the appearance of ultrafine particles occurs when clear sky is observed immediately after an in cloud period. In the case of 5 July, where the appearance of ultra-fine particles appeared to be measured within cloud, we propose that either the cloud top was low enough that entrainment of small particles from the cloud top occurred, or that the cloud was thin enough to allow sufficient transmission of 


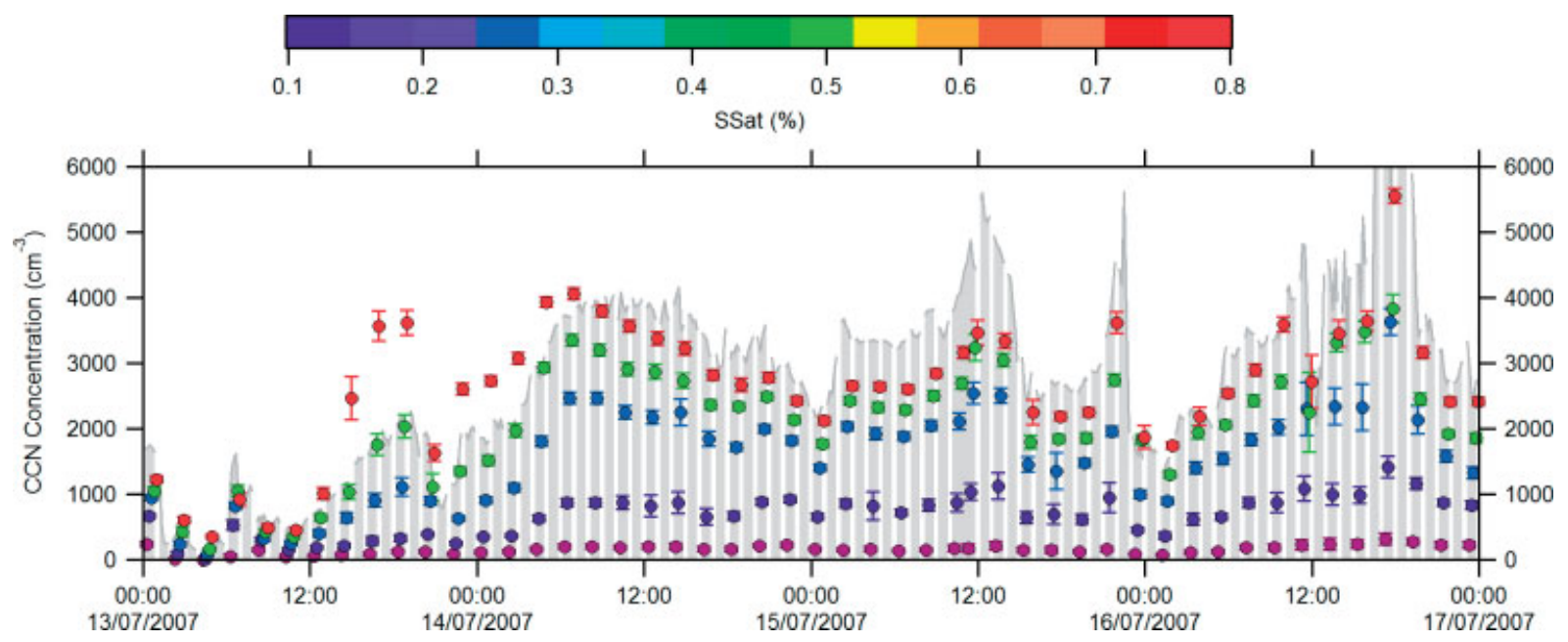

Figure 6. Time series of CCN concentration $\left(\mathrm{cm}^{-3}\right)$ at measured supersaturations (\%) denoted by the colour scale at the top of the figure. Also shown in grey is the total number concentration from the L-DMPS for particles $>100 \mathrm{~nm}$. Total DMPS concentration reached $\sim 35000 \mathrm{~cm}^{-3}$ on $^{13} \mathrm{July}$ (not shown here).

solar radiation to allow photochemical formation of lowvolatility productions, which then nucleate new particles.

\section{Discussion}

Aerosol particles, for the most part, were found to be an internal mixture of organic, sulphate, nitrate, ammonium and black carbon, with the high-resolution AMS data suggesting that the organic material was likely to be highly oxidised.

In central Europe, away from the coast, any detected sulphate is likely to be anthropogenic in origin (Schlesinger, 1997). If the detected organic material were of anthropogenic source, there should be an expected association with either anthropogenic primary (e.g. BC) or secondary (e.g. sulphate) aerosol. As Figure 3 shows, there is no good association between the AMS organic signal and the MAAP BC signal and neither is there a good association with the AMS sulphate signal; suggesting that the organic material is not of anthropogenic origin. This suggests that the high mass concentrations of organic material detected during COPS were most likely of biogenic origin, though this cannot be confirmed using the AMS dataset. Figure 3 also shows that sulphate is correlated with $\mathrm{BC}$ for the majority of the project, implying that the sulphate material is from an anthropogenic source. The BC and sulphate mass loadings were low for the entire measurement period, $<1 \mu \mathrm{g} \mathrm{m}^{-3}$ and $<2 \mu \mathrm{g} \mathrm{m}^{-3}$ respectively.

Recent measurements across Europe using a compact time-of-flight (cToF)-AMS on board the BAE-146 aircraft (Morgan et al., 2009) have shown that aerosol particles across Europe are dominated by organic and ammonium nitrate mass, each accounting for $20-50 \%$ of the measured mass. They also showed that concentrations of organic material generally exceed sulphate by a factor of 1.5-2.0 and that organic mass was a significant component during background and polluted conditions. Morgan et al. (2009) reported sulphate mass loadings typically of $1.0-3.5 \mu \mathrm{g} \mathrm{m}^{-3}$, accounting for $10-30 \%$ of the mass fraction. They reported increases in nitrate concentration associated with enhanced total mass loading, indicating an association with highly polluted conditions. Zhang et al. (2007) carried out a similar study for 37 field studies across the Northern Hemisphere where it was also reported that organic aerosol represented a major fraction (18-70\%: 45\% average) of the aerosol mass. Inorganic species were reported as: sulphate 10-67\% (32\% average); nitrate $1.2-28 \%$ (10\% average); ammonium $6.9-19 \%$ (13\% average). Several locations close to the COPS region were included in this study, where $\sim 55 \%$ of aerosol mass was organic material in Taunus, Germany, $\sim 45 \%$ in Mainz, Germany, $50 \%$ in Hohenpeissenberg, Germany and 30\% at Jungfraujoch, Switzerland. Comparison of the COPS data with these figures shows that the concentration of organic material measured during the COPS campaign is relatively high. The data in this paper show that organic mass loadings exceeded $9 \mu \mathrm{g} \mathrm{m}^{-3}$ on 16 July during the HP period, accounting for up to $80 \%$ of the mass composition. The organic to sulphate mass ratio exceeded 10:1 on three days during the first half of the HP period, then reduced to around 3:1 for the second half of HP, much larger values than those reported in Morgan et al. (2009). When the organic:sulphate ratio was lower, it is possible that there were increased contributions from anthropogenic sources further afield, as the back trajectories suggest. This could also result in increased contributions of anthropogenic organic material to the total organic loadings. Organic:BC mass ratio exceeded $12: 1$ on 15 July; this is also a very high ratio, previous studies reveal values of $1.5-4$ when considering PM2.5 and PM10 measurements in and around cities (Putaud et al., 2004).

Drewnick et al. (2007), as part of a Swedish ground-site study, reported consistently high organic mass loadings, with large concentrations of organic material when back trajectories had passed over southern Finland. It was suggested that this could be the result of photochemistry generating aerosol or increasing condensational growth of existing particles from organic vapours emitted from the forests on the Scandinavian peninsula, possibly by the photo-oxidation of vapours known to be emitted in large amounts by the Finnish forests (Kulmala et al., 2004a, 2004b). Drewnick et al. (2007) also reported that the detected sulphate component was likely a more aged component, that was mainly found when air masses passed over continental Europe or Great Britain. 
Similar to the work carried out by Drewnick et al. (2007), an investigation into the air mass history has been performed for COPS. During COPS, the maximum sulphate loading occurred on 9 July during a particularly strong ultrafine particle event. Wind direction and speed does not change much across this period, with wind coming from the west at around $4 \mathrm{~m} \mathrm{~s}^{-1}$. A second sulphate peak is seen around midnight of 23/24 July. The ultrafine particle event on the days either side is not particularly strong compared to other days. Sulphate decrease is associated with a change in local wind speed from 2 to $4 \mathrm{~m} \mathrm{~s}^{-1}$ and a change in wind direction from $\sim 270^{\circ}$ to $\sim 100^{\circ}$. Investigation of back trajectories (BTs) initiated at the Hornisgrinde site and $50 \mathrm{~m}$ to the north, south, east and west, at five pressure levels for the previous five days before arrival at the site show BTs approaching the site from the west after passing across France. BTs from 9 July show the air masses coming from over the North Atlantic over the southern edges of Ireland and England before reaching France, whereas on 23 July air masses come from over the Atlantic to approach France from just north of mainland Spain. For both of these cases, the sulphate could be marine in nature, either natural (e.g. Seguin et al., 2010) or from shipping (e.g. Endresen et al., 2010). On 9 July there could also have been some urban influences from the air mass passing over the United Kingdom.

BTs from nitrate days, e.g. 19 July, show air masses approaching the site from a north or northwest direction having looped around to the northwest of the site either first passing over central Spain from the Atlantic, or passing over central Italy from Scandinavia. The nitrate is believed to have originated from the Stuttgart region, either from agricultural or urban sources. The National Aeronautical and Space Administration (NASA) Moderate resolution Imaging Spectroradiometer (MODIS) database shows that the city of Stuttgart is an urban/built-up area surrounded by mixed forest and crop lands. Strong organic mass loadings are seen when BTs show air masses spending a long time over the Black Forest region. This is a potential source of lots of biogenic emissions, particularly on sunny days as has been noted in other studies (e.g. Slowik et al., 2010).

Aerosol water uptake in the sub- and supersaturated regimes were measured simultaneously by an HTDMA and CCNc respectively. Peak growth factor was found to increase with particle dry diameter. Particles of size 26-85 $\mathrm{nm}$ are mostly classified as less hygroscopic according to Swietlicki et al. (2008). Particles of size $85 \mathrm{~nm}$ during HPW had peak growth factors up to 1.5 , definitely within the more-hygroscopic classification range. The HP period shows the smallest variability in peak growth factor, probably due to the consistent composition throughout this period. Comparison of the COPS growth factor values with those reported in McFiggans et al. (2006) reveal that aerosol particles measured at the Hornisgrinde site could fit with previous measurements of urban, continental polluted and/or biogenically dominated aerosol. McFiggans et al. (2006) report that biogenically dominated aerosol between 50 and $80 \mathrm{~nm}$ exhibit a primary peak between 1.15 and 1.20 and a potential secondary peak $\sim 1.07$. This indicates that growth factor measurements are consistent with the hypothesis that the organic aerosol is of biogenic origin based on an analysis of air mass history. The higher peaks in growth factors are therefore likely to be from urban or continental polluted aerosol, which have their primary peaks at $1.15-1.43$ and $1.32-1.53$ respectively. A similar situation is seen for $127-169 \mathrm{~nm}$ dry size diameter particles when compared to $100-150 \mathrm{~nm}$ particles in McFiggans et al. (2006). All particles measured during the HP period were classified as less-hygroscopic using the scheme of Swietlicki et al. (2008). The HPW period show the widest spread in peak growth factors reaching the highest values. At larger sizes during the WF1 period, aerosols are classified as more-hygroscopic. It is important to remember that the peak growth factor measurements during WF1 will be related to when the site was out of cloud. Investigation into the effect of inorganic:organic ratio on the growth factor by Irwin et al. (2010) has revealed that there is no apparent correlation.

A time series of modal growth factor from the HTDMA-measured growth factor for $127 \mathrm{~nm}$ particles was constructed. Modal growth factor was chosen over mean growth factor, as for parts of the COPS project the GF distribution was bimodal and the secondary peak (usually $G F=1$ ) brings the mean down. We then fit the value of the $G F($ org) to match the predicted GF from Zdanovskii-Stokes-Robinson (ZSR) calculations (using non-size-resolved composition measurements from the AMS) to the modal times series. A density of $1.4 \mathrm{~g} \mathrm{~cm}^{-3}$ for bulk organic material (e.g. Alfarra et al., 2006) was used for this calculation along with assumed GF for the inorganic species as predicted by the Aerosol Diameter Dependent Equilibrium Model (ADDEM: Topping et al., 2005a, 2005b) at $86 \% \mathrm{RH}, 20{ }^{\circ} \mathrm{C}$, for $127 \mathrm{~nm}$ diameter particles. The result of this calculation can be represented as a probability distribution of the required $G F($ org $)$ to produce the modal $G F$ (total). This distribution has a peak at 1.1 (corresponding to a kappa(org,127 nm) of 0.267 ; calculated using equation 11 in Petters and Kreidenweis (2007)), with $66 \%$ of the required GF between 1.0 and $1.2,29 \%$ between 0.6 and 0.95 and only $5 \%$ between 1.25 and 2.0. The predicted GF values $<1.0$ were found to be from times when the nitrate signal from the AMS was greater than $20 \%$ of the total composition, e.g. 19 July. It has been reported in previous field studies (e.g. Gysel et al., 2007) that the presence of ammonium nitrate can cause the ZSR-predicted GF to be higher than the modal GF measured by the HTDMA. This is suggested to be due to evaporation of semi-volatiles in the HTDMA (e.g. ammonium nitrate) resulting in the HTDMA measuring a GF of a resultant composition that is different to what the AMS records and the ZSR calculation is performed on. This work must be treated with caution, as several assumptions have been made. Firstly, the ZSR calculations were made using bulk AMS compositional measurements, which are perhaps not representative of the exact composition at $127 \mathrm{~nm}$. However, the signal: noise ratio of the size-resolved mass composition of the organics is not sufficient to allow a more detailed calculation in this case. We also note that the density of the organic material could vary over time. We have no direct measurement of this, but we have used 1.4 here as is reported in the literature (e.g. Alfarra et al., 2006).

Particle growth factors during COPS, as determined from HTDMA measurements, were typically lower than those seen during the marine experiment 'RHaMBLe' (primary GF mode $\sim 1.5-1.8$, secondary GF mode $\sim 2$ (Good et al., $2010 \mathrm{~b})$ ); which is most likely due to the continental origin of the aerosol in this study. Critical supersaturations were 

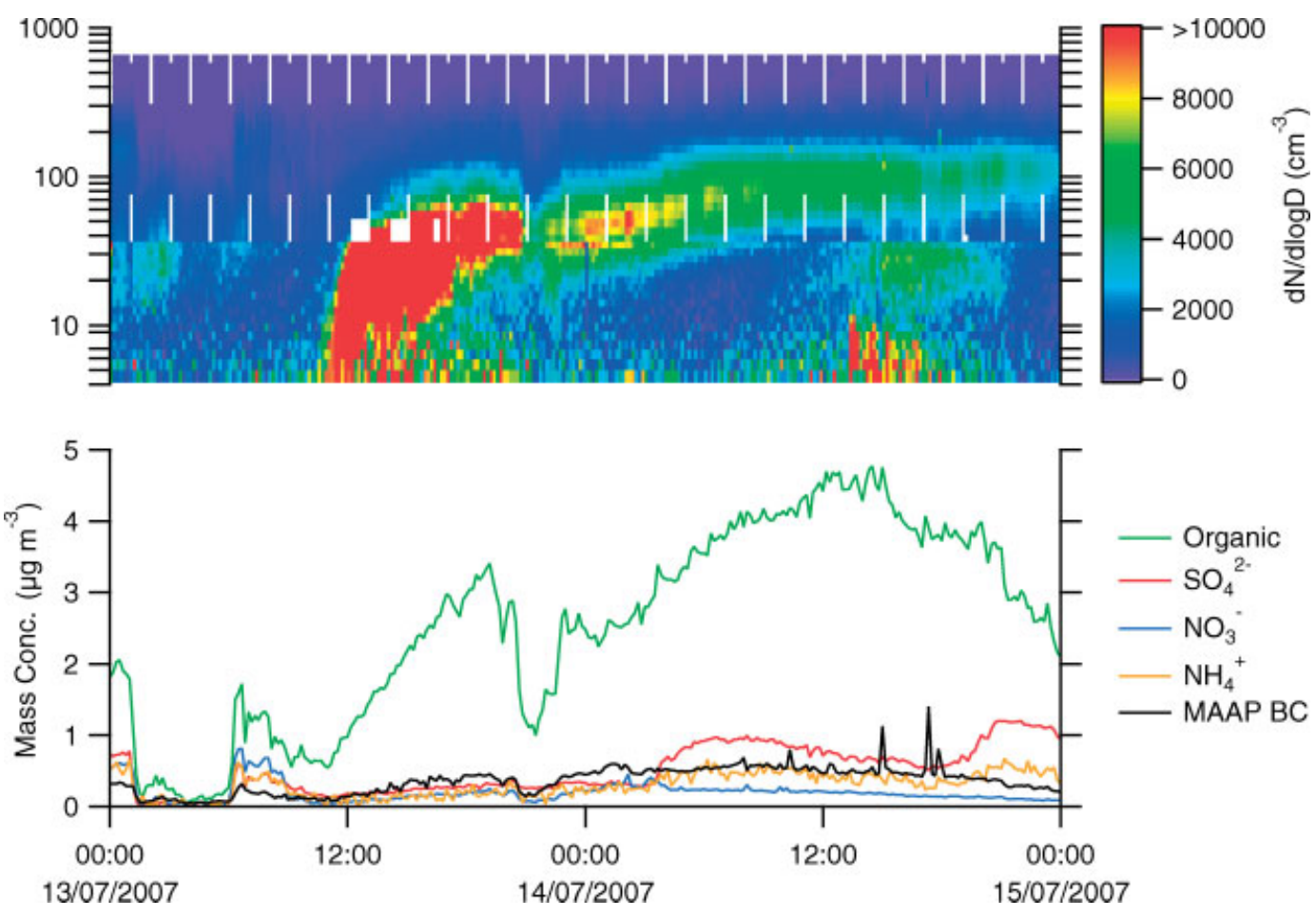

Figure 7. Time series of DMPS number size distribution and compositional data (AMS and MAAP) for the start of the HP period.

typically higher for COPS than RHaMBLe; this can be seen by comparing Figure 5 in Irwin et al. (2010) to the lower panel of Figure 7 in Good et al. (2010b). The hygroscopic measurements made at COPS are in keeping with those from other continental studies. Good et al. (2010b) reported $\kappa$ values between 0.3 and 0.7 for the RHaMBLe project. Rose et al. (2008) reported $\kappa$ values derived from CCNc measurements of 0.3 for continental aerosol. Kammermann et al. (2009) reported $\kappa$ values derived from HTDMA measurements of 0.17 to 0.31 , where similar values at all sizes were seen, indicating internally mixed aerosol. Kreidenweis et al. (2006) reported highly CCN-active salts to have a $\kappa$ value of $0.5-2$, organic aerosols to have $\kappa$ values of 0.01 to 0.5 and non-hygroscopic components to have a $\kappa$ value of 0 , using CCN measurements. Kappa values from CCN measurements during the FLAME-II campaign were reported to be between 0.02 and 0.8 for laboratory biomass burning (Petters et al., 2009b). The values from COPS are consistent with previous measurements of organic material. A more in-depth study on the effects of composition on particle water uptake for COPS, potential cloud droplet number concentrations $(\mathrm{CDNc})$ and closure between the two saturation regimes are presented in Irwin et al. (2010).

During high pressure periods, high concentrations of SOA derived from organic photochemistry appear to drive the substantial growth of the nucleation-mode aerosol to accumulation-mode sizes; an indication of this can be seen in Figure 7. During a period of $\sim 12$ hours on 14 July, the peak in the number size distribution moves from 40 to $80 \mathrm{~nm}$, and this can be seen to strongly link with the increase in organic mass loadings from $\sim 1$ to $\sim 4 \mu \mathrm{g} \mathrm{m}^{-3}$. During the HP period, starting on 13 July, there appears to be a diurnal cycle of organic mass loadings linked to the solar radiance over the site. Under these high pressure conditions, clear skies and low wind speeds drive active photochemistry, and the lack of advection will enhance the relative contribution near sources to the burden of precursor material. In addition, the high temperature and increased radiation will favour enhanced biogenic emissions. All these variables favour the contribution of biogenic material to the SOA burden. While none of this is direct evidence, it is entirely consistent with a large number of other studies in the literature (e.g. Kulmala et al., 2004b). This situation has been observed in other studies, e.g. Ristovski et al. (2010) in Tumbarumba, New South Wales, Australia and Allan et al. (2006) in Hyytiälä, Finland. Evidence for organic material responsible for the majority of a particle's growth has also been reported in coastal environments, e.g. Modini et al. (2009) in Agnes Water, Queensland, Australia. This condensational growth onto pre-existing particles allows particles to reach climatically relevant sizes and significantly enhances the CCN activity of those particles (Figure 6); this has also been shown in previous studies. Ehn et al. (2007) reported an increase of 0.05 in the mean measured growth factor at noon for days when new particle formation was observed, compared to days when it was not. In addition a positive correlation between $\mathrm{H}_{2} \mathrm{SO}_{4}$ and growth factor was observed, more evident for smaller particles. At larger sizes, it was suggested that additional soluble organic compounds condensed onto the particles, reducing the correlation to $\mathrm{H}_{2} \mathrm{SO}_{4}$. These numbers are also consistent with Gysel et al. (2007), where it was reported that a growth factor of $1.20 \pm 0.1$ was suitable for modelling organic material. The conditions required for high organic mass loadings, along with low wind speeds, are also conducive to the production of convective available potential energy (CAPE) in the region.

\section{Conclusion}

This paper presents the size and compositional and hygroscopic properties of aerosol particles measured at the Hornisgrinde Mountain site during the summer 2007 
COPS field campaign. The campaign was separated into four periods, determined by meteorological conditions. The main finding was the high fractional organic mass composition (generally $>40 \%$ ) present throughout the project, and increasing to provide over $70 \%\left(>8 \mu \mathrm{g} \mathrm{m}^{-3}\right)$ of the aerosol mass during the period of high pressure, when high temperature and low wind speed were also observed. AMS data reveal that the organic material was oxidised. Sulphate and black carbon mass loading do not exceed $2 \mu \mathrm{g} \mathrm{m}^{-3}$; ammonium mass loadings do not exceed $1 \mu \mathrm{g} \mathrm{m}^{-3}$. Nitrate mass loadings are mostly very low, with the exception of 19 July, when the peak was around $3 \mu \mathrm{g} \mathrm{m}^{-3}$. Organic:sulphate and organic:BC mass concentration ratios during this time exceeds 10:1. Values are generally greater than 2:1 for the entire COPS period. These measurements are for the most part consistent with previous work (e.g. Drewnick et al., 2007; Morgan et al., 2009). Back trajectories during the high pressure period show the air mass track passing slowly over the Black Forest close to the measurement site. As such, we argue that the detected organic material during this time-frame was photo-oxidised biogenic in nature, although this cannot be confirmed with the current dataset. Back trajectories and local wind measurements showed that, for the most part, air approached the measurement site from the southwest. Changes in the compositional trend are associated with changes in the air mass track as shown by back-trajectory analysis. Nitrate peaks are associated with north-westerly air flow over the Stuttgart region. Sulphate peaks are associated with aged air that passed over the Republic of Ireland and southern England or mainland Spain, in addition to a host of major shipping lanes in the eastern Atlantic Ocean.

Aerosol particle size distribution data showed the domination of the accumulation-mode during times when the site was unaffected by precipitation events. The appearance of high numbers of ultrafine particles was detected on most days, commencing around noon. These ultrafine aerosol particles appear to grow due to the condensational growth of organic material.

Hygroscopic properties (growth factor, kappa values and critical supersaturation) of the particles measured during COPS are similar to those measured in previous continental field campaigns. Growth factor distributions were typically bimodal, with a less-hygroscopic and morehygroscopic peak. During the HP period when organic material dominated, only the peak at 1.2 was seen. This is consistent with Gysel et al. (2007), where they reported that a growth factor of $1.20 \pm 0.1$ was suitable for modelling organic material. Derived kappa values from both the CCN and HTDMA instruments are also consistent with previous studies of continental air masses (e.g. Rose et al., 2008; Kammermann et al., 2009).

\section{Acknowledgements}

We thank the FAAM, the UK Met Office, Avalon and DirectFlight personnel for their contributions to the campaign. Data from other sources were accessed via the Climate and Environmental Retrieving and Archiving (CERA) website provided by the World Data Centre for Climate (WDCC), Hamburg, Germany. Automatic weather station data were provided by Innsbruck University, Austria. Cloud radar data were provided by the Institüt für Meteorologie und Klimaforschung, Forschungszentrum
Karlsruhe, Germany. The UK Met Office supplied NIMROD data used in the creation of the animation in the supplementary material. Back trajectories were provided by the British Atmospheric Data Centre (BADC) trajectory service. COPS was funded by NERC grant: NE/E016200/1. Martin Irwin was funded under studentship grant number: NER/S/A/2006/14036.

\section{References}

Aiken AC, Salcedo D, Cubison MJ, Huffman JA, DeCarlo PF, Ulbrich IM, Docherty KS, Sueper D, Kimmel JR, Worsnop DR, Trimborn A, Northway M, Stone EA, Schauer JJ, Volkamer RM, Fortner E, de Foy B, Wang J, Laskin A, Shutthanandan V, Zheng J, Zhang R, Gaffney J, Marley NA, Paredes-Miranda G, Arnott WP, Molina LT, Sosa G, Jimenez JL. 2009. Mexico City aerosol analysis during MILAGRO using high resolution aerosol mass spectrometry at the urban supersite (T0) - Part 1: Fine particle composition and organic source apportionment. Atmos. Chem. Phys. 9: 6633-6653.

Alfarra MR, Paulsen D, Gysel M, Garforth AA, Dommen J, Prévôt ASH, Worsnop DR, Baltensperger U, Coe H. 2006. A mass spectrometric study of secondary organic aerosols formed from the photooxidation of anthropogenic and biogenic precursors in a reaction chamber. Atmos. Chem. Phys. 6: 5279-5293.

Allan JD, Jimenez JL, Williams PI, Alfarra MR, Bower KN, Jayne JT, Coe H, Worsnop DR. 2003. Quantitative sampling using an Aerodyne aerosol mass spectrometer. 1: Techniques of data interpretation and error analysis. J. Geophys. Res. 108: 4090, DOI: 10.1029/2002JD002358.

Allan JD, Delia AE, Coe H, Bower KN, Alfarra MR, Jimenez JL, Middlebrook AM, Drewnick F, Onasch TB, Canagaratna MR, Jayne JT, Worsnop DR. 2004. A generalised method for the extraction of chemically resolved mass spectra from Aerodyne aerosol mass spectrometer data. J. Aerosol Sci. 35: 909-922.

Allan JD, Alfarra MR, Bower KN, Coe H, Jayne JT, Worsnop DR, Aalto PP, Kulmala M, Hyötyläinen T, Cavalli F, Laaksonen A. 2006. Size and composition measurements of background aerosol and new particle growth in a Finnish forest during QUEST 2 using an Aerodyne aerosol mass spectrometer. Atmos. Chem. Phys. 6: 315-327.

Allan JD, Williams PI, Morgan WT, Martin CL, Flynn MJ, Lee J, Nemitz E, Phillips GJ, Gallagher MW, Coe H. 2010. Contributions from transport, solid fuel burning and cooking to primary organic aerosols in two UK cities. Atmos. Chem. Phys. 10: 647-668.

Canagaratna MR, Jayne JT, Jimenez JL, Allan JD, Alfarra MR, Zhang Q, Onasch TB, Drewnick F, Coe H, Middlebrook A, Delia A, Williams LR, Trimborn AM, Northway MJ, DeCarlo PF, Kolb CE, Davidovits P, Worsnop DR. 2007. Chemical and microphysical characterization of ambient aerosols with the Aerodyne aerosol mass spectrometer. Mass Spectrom. Rev. 26: 185-222.

Cocker DR, Whitlock NE, Flagan RC, Seinfeld JH. 2001. Hygroscopic properties of Pasadena, California aerosol. Aerosol Sci. Technol. 35: 637-647.

Cubison MJ, Coe H, Gysel M. 2005. A modified hygroscopic tandem DMA and a data retrieval method based on optimal estimation. J. Aerosol Sci. 36: 846-865.

DeCarlo PF, Dunlea EJ, Kimmel JR, Aiken AC, Sueper D, Crounse J, Wennberg PO, Emmons L, Shinozuka Y, Clarke A, Zhou J, Tomlinson J, Collins DR, Knapp D, Weinheimer AJ, Montzka DD, Campos T, Jimenez JL. 2008. Fast airborne aerosol size and chemistry measurements above Mexico City and central Mexico during the MILAGRO campaign. Atmos. Chem. Phys. 8: 4027-4048.

Denman KL, Brasseur G, Chidthaisong A, Ciais P, Cox PM, Dickinson RE, Hauglustaine D, Heinze C, Holland E, Jacob D, Lohmann U, Ramachandran S, da Silva Dias PL, Wofsy SC, Zhang X. 2007. Couplings between changes in the climate system and biogeochemistry. Pp 500-556 in Climate Change 2007: The Physical Science Basis. Contribution of Working Group I to the Fourth Assessment Report of the Intergovernmental Panel on Climate Change, Soloman S, et al. (eds). Cambridge University Press: Cambridge, UK.

Drewnick F, Schneider J, Hings SS, Hock N, Noone K, Targino A, Weimer S, Borrmann S. 2007. Measurement of ambient, interstitial, and residual aerosol particles on a mountaintop site in central Sweden using an aerosol mass spectrometer and a CVI. J. Atmos. Chem. 56: $1-20$.

Ehn M, Petäjä T, Aufmhoff H, Aalto P, Hämeri K, Armold F, Laaksonen A, Kulmala M. 2007. Hygroscopic properties of ultrafine aerosol particles in the boreal forest: Diurnal variation, solubility and the influence of sulfuric acid. Atmos. Chem. Phys. 7: 211-222. 
Endresen $\emptyset$, Eide MS, Dalsøren S, Sørgård ISIE, Corbett JJ, Winebrake J. 2010. Chapter 6: International maritime shipping: Environmental impacts of increased activity levels. Pp 161-178 in Globalisation Transport and the Environment. Organization for Economic Cooperation and Development. OECD Publishing.

Facchini MC, Mircea M, Fuzzi S, Charlson RJ. 1999. Cloud albedo enhancement by surface-active organic solutes in growing droplets. Nature 401: 257-259.

Facchini MC, Decesari S, Mircea M, Fuzzi S, Loglio G. 2000. Surface tension of atmospheric wet aerosol and cloud/fog droplets in relation to their organic carbon content and chemical composition. Atmos. Environ. 34: 4853-4857.

Forster P, Ramaswamy V, Artaxo P, Berntsen T, Betts R, Fahey DW, Haywood J, Lean J, Lowe DC, Myhre G, Nganga J, Prinn R, Raga G, Schulz M, Dorland RV. 2007. Changes in atmospheric constituents and in radiative forcing. Pp 129-234 in Climate Change 2007: The Physical Science Basis, Solomon S, et al. (eds). Cambridge University Press: Cambridge and New York.

Good N, Topping DO, Duplissy J, Gysel M, Meyer NK, Metzger A, Turner SF, Baltensperger U, Ristovski Z, Weingartner E, Coe H, McFiggans G. 2010a. Widening the gap between measurement and modelling of secondary organic aerosol properties? Atmos. Chem. Phys. 10: 2577-2593.

Good N, Topping DO, Allan JD, Flynn M, Fuentes E, Irwin M, Williams PI, Coe H, McFiggans GB. 2010b. Consistency between parameterisations of aerosol hygroscopicity and $\mathrm{CCN}$ activity during the RHaMBLe discovery cruise. Atmos. Chem. Phys. 10: 3189-3203.

Gysel M, Crosier J, Topping DO, Whitehead JD, Bower KN, Cubison MJ, Williams PI, Flynn MJ, McFiggans GB, Coe H. 2007. Closure study between chemical composition and hygroscopic growth of aerosol particles during TORCH2. Atmos. Chem. Phys. 7: 6131-6144.

Hämeri K, Väkevä M, Aalto PP, Kulmala M, Swietlicki E, Zhou J, Seidl W, Becker E, O'Dowd CD. 2001. Hygroscopic and CCN properties of aerosol particles in boreal forests. Tellus 53B: 359-379.

Hamilton JF, Webb PJ, Lewis AC, Hopkins JR, Smith S, Davy P. 2004. Partially oxidised organic components in urban aerosol using GCXGC-TOF/MS. Atmos. Chem. Phys. 4: 1279-1290.

Hanford KL, Mitchem L, Reid JP, Clegg SL, Topping DO, McFiggans GB 2008. Comparative thermodynamics studies of aqueous glutaric acid, ammonium sulfate and sodium chloride aerosol at high humidity. J. Phys. Chem. A 112: 9413-9422.

Hauf T, Witte N. 1985. Fallstudie eines nächtlichen Windsystems, Meteorol. Rundschau 38: 33-42.

Hoppel WA, Frick GM, Fitzgerald JW, Wattle BJ. 1994. A cloud chamber study of the effect that nonprecipitating water clouds have on the aerosol size distribution. Aerosol Sci. Technol. 20: 1-30.

Hoyle CR, Boy M, Donahue NM, Fry JL, Glasius M, Guenther A, Hallar AG, Huff Hartz K, Petters MD, Petäjä T, Rosenoern T, Sullivan AP. 2010. Anthropogenic influence on biogenic secondary organic aerosol. Atmos. Chem. Phys. Discuss. 10: 19515-19566.

Irwin M, Good N, Crosier J, Choularton TW, McFiggans G. 2010 Reconciliation of measurements of hygroscopic growth and critical supersaturation of aerosol particles in southwest Germany. Atmos. Chem. Phys. Discuss. 10: 17073-17111.

Jacobson MC, Hansson H-C, Noone KJ, Charlson RJ. 2000. Organic atmospheric aerosols: Review and state of the science. Rev. Geophys. 38: $267-294$.

Jimenez JL, Bahreini D, Cocker DR, Zhuang H, Varutbangkul V, Flagan RC, Seinfeld JH, O'Dowd CD, Hoffmann T. 2003. New particle formation from photooxidation of diiodomethane $\left(\mathrm{CH}_{2} \mathrm{I}_{2}\right)$. J. Geophys. Res. 108: 4318, DOI: 10.1029/2002JD002452.

Jimenez JL, Canagaratna MR, Donahue NM, Prévôt ASH, Zhang Q, Kroll JH, DeCarlo PF, Allan JD, Coe H, Ng NL, Aiken AC, Docherty KS, Ulbrich IM, Grieshop AP, Robinson AL, Duplissy J, Smith JD, Wilson KR, Lanz VA, Hueglin C, Sun YL, Tian J, Laaksonen A, Raatikainen T, Rautiainen J, Vaattovaara P, Ehn M, Kulmala M, Tomlinson JM, Collins DR, Cubison MJ, Dunlea EJ, Huffman JA, Onasch TB, Alfarra MR, Williams PI, Bower K, Kondo Y, Schneider J, Drewnick F, Borrmann S, Weimer S, Demeriian K, Salcedo D, Cottrell L, Griffin R, Takami A, Miyoshi T, Hatakeyama S, Shimono A, Sun JY, Zhang YM, Dzepina K, Kimmel JR, Sueper D, Jayne JT, Herndon SC, Trimborn AM, Williams LR, Wood EC, Middlebrook AM, Kolb CE, Baltensperger U, Worsnop DR. 2009 Evolution of organic aerosols in the atmosphere. Science 326: $1525-1529$.

Kalthoff N, Vogel B. 1992. Counter-current and channelling effect under stable stratification in the area of Karlsruhe. Theor. Appl. Climatol. 45: $113-126$.

Kammermann L, Gysel M, Weingartner E, Baltensperger U. 2009. 'A full year of aerosol hygroscopicity measurements at the High Alpine
Research Station Jungfraujoch (3580 m asl.).' Conference proceedings to American Geophysical Union, Fall Meeting 2009.

Kazil J, Stier P, Zhang K, Quass J, Kinne S, O’Donnell D, Rast S, Esch M, Ferrachat S, Lohmann U, Feichter J. 2010. Aerosol nucleation and its role for clouds and Earth's radiative forcing in the aerosolclimate model ECHAM5-HAM. Atmos. Chem. Phys. Discuss. 10: $12261-12308$.

Khain A, Pokrovsky A. 2004. Simulation of effects of atmospheric aerosols on deep turbulent convective clouds using a spectral microphysics mixed-phase cumulus cloud model. Part II: Sensitivity study. J. Atmos. Sci. 61: 2983-3001.

King SM, Rosenoern T, Shilling JE, Chen Q, Martin ST. 2009. Increased cloud activation potential of secondary organic aerosol for atmospheric mass loadings. Atmos. Chem. Phys. 9: 2959-2971.

Kirkevåg A, Iversen T. 2002. Global direct radiative forcing by processparameterized aerosol optical properties. J. Geophys. Res. 107: 4433, DOI: 10.1029/2001JD000886.

Kiss G, Tombácz E, Hansson H-C. 2005. Surface tension effects of humic-like substances in the aqueous extract of tropospheric fine aerosol. J. Atmos. Chem. 50: 279-294.

Kokkola H, Sorjamaa R, Peräniemi A, Raatikainen T, Laaksonen A. 2006. Cloud formation of particles containing humic-like substances. Geophys. Res. Lett. 33: L10816, DOI: 10.1029/2006GL026107.

Kossmann M. 1992. 'Deformation des vertikalen Geschwindigkeitsprofils und der Turbulenzintensität bei der Überströmung einer Bergkette.' Diplomarbeit. Institut für Meteorologie und Klimaforschung Karlsruhe, 86 pp.

Kossmann M, Corsmeier U, De Wekker SFJ, Fiedler F, Vögtlin R, Kalthoff N, Güsten H, Neininger B. 1999. Observations of handover processes between the atmospheric boundary layer and the free troposphere over mountainous terrain. Contrib. Atmos. Phys. 72: 329-350.

Kreidenweis S, Petters M, Demott P, Prenni A, Ziemann P. 2006. 'Parameterization of the cloud nucleating activity of fresh, aged, and internally-mixed organic aerosols.' Conference proceedings to American Geophysical Union, Fall Meeting 2006.

Kulmala M, Pirjola U, Mäkelä JM. 2000. Stable sulphate clusters as a source of new atmospheric particles. Nature 404: 66-69.

Kulmala M, Laakso L, Lehtinen KEJ, Riipinen I, Del Maso M, Anttila T, Kerminen V-M, Hörrak U, Vana M, Tammet H. 2004a. Initial steps of aerosol growth. Atmos. Chem. Phys. 4: 2553-2560.

Kulmala M, Vehkamäki H, Petäjä T, Dal Maso M, Lauri A, Kerminen VM, Birmili W, McMurry PH. 2004b. Formation and growth rates of ultrafine atmospheric particles: A review of observations. J. Aerosol. Sci. 35: 143-176.

Lanz VA, Alfarra MR, Baltensperger U, Buchmann B, Hueglin C, Prévôt ASH. 2007. Source apportionment of submicron organic aerosols at an urban site by factor analytical modelling of aerosol mass spectra. Atmos. Chem. Phys. 7: 1503-1522.

Lynn B, Khain A, Rosenfeld D, Woodley WL. 2007. Effects of aerosols on precipitation from orographic clouds. J. Geophys. Res. 112: D10225, DOI: 10.1029/2006JD007537.

McFiggans GB, Alfarra MR, Allan J, Bower K, Coe H, Cubison M, Topping DO, Williams PI, Decesari S, Facchini C, Fuzzi S. 2005. Simplification of the representation of the organic component of atmospheric particulates. Faraday Discuss. 130: 341-362.

McFiggans GB, Artaxo P, Baltensperger U, Coe H, Facchini MC, Feingold G, Fuzzi S, Gysel M, Laaksonen A, Lohmann U, Mentel TF, Murphy DM, O'Dowd CD, Snider JR, Weingartner E. 2006. The effect of physical and chemical aerosol properties on warm cloud droplet activation. Atmos. Chem. Phys. 6: 2593-2649.

McMurry PH, Litchy M, Huang P-F, Cai X, Turpin BJ, Dick WD, Hanson A. 1996. Elemental composition and morphology of individual particles separated by size and hygroscopicity with the TDMA. Atmos. Environ. 30: 101-108.

Maßling A, Wiedensohler A, Voutilainen A. 2003. 'Hygroscopic properties of submicrometer aerosol particles during ACE-Asia.' Pp S9-S10 in Abstracts of the European Aerosol Conference 2003, Vol. 1.

Merikanto J, Spracklen DV, Mann GW, Pickering SJ, Carslaw KS. 2009. Impact of nucleation on global CCN. Atmos. Chem. Phys. 9; $8601-8616$

Millán MM, Salvador R, Mantilla E, Kallos G. 1997. Photooxidant dynamics in the Mediterranean basin in summer: Results from European research projects. J. Geophys. Res. 102: 8811-8823.

Modini RL, Ristovski ZD, Johnson GR, He C, Surawski N, Morawska L, Suni T, Kulmala M. 2009. New particle formation and growth at a remote, sub-tropical coastal location. Atmos. Chem. Phys. 9: $7607-7621$.

Mönkkönen P, Koponen IK, Lehtinen KEJ, Hämeri K, Uma R, Kulmala M. 2005. Measurements in a highly polluted Asian mega 
city: Observations of aerosol number size distribution, modal parameters and nucleation events. Atmos. Chem. Phys. 5: 57-66.

Morgan WT, Allan JD, Bower KN, Highwood EJ, Liu D, McMeeking GR, Northway MJ, Williams PI, Krejci R, Coe H. 2009. Airborne measurements of the spatial distribution of aerosol chemical composition across Europe and evolution of the organic fraction. Atmos. Chem. Phys. Discuss. 9: 27215-27265.

Muhlbauer A, Lohmann U. 2008. Sensitivity studies of the role of aerosols in warm-phase orographic precipitation in different dynamical flow regimes. J. Atmos. Sci. 65: 2522-2542.

O'Dowd CD, Facchini MC, Cavalli F, Ceburnis D, Mircea M, Decesari S, Fuzzi S, Yoon YJ, Putaud J-P. 2004. Biogenically driven organic contribution to marine aerosol. Nature 431: 676-680.

Petters MD, Kreidenweis SM. 2007. A single parameter representation of hygroscopic growth and cloud condensation nucleus activity. Atmos. Chem. Phys. 7: 1961-1971.

Petters MD, Wex H, Carrico CM, Hallbauer E, Maßling A, McMeeking GR, Poulain L, Wu Z, Kreidenweis SM, Stratmann F. 2009a. Towards closing the gap between hygroscopic growth and activation for secondary organic aerosol - Part 2: Theoretical approaches. Atmos. Chem. Phys. 9: 3999-4009.

Petters MD, Carrico CM, Kreidenweis SM, Prenni AJ, DeMott PJ, Collett JL, Moosmüller H. 2009b. Cloud condensation nucleation activity of biomass burning aerosol. J. Geophys. Res. 114: D22205, DOI: 10.1029/2009JD012353.

Petzold A, Kramer H, Schoenlinner M. 2002. Continuous measurement of atmospheric black carbon using a multi-angle absorption photometer. Environ. Sci. Pollution Res. Int. 9: 78-82.

Prisle NL, Raatikainen T, Sorjamaa R, Svenningsson B, Laaksonen A, Bilde M. 2008. Surfactant partitioning in cloud droplet activation: A study of C8, C10, C12 and C14 normal fatty acid sodium salts. Tellus 60B: $416-431$

Putaud J-P, Raes F, Van Dingenen R, Brüggemann E, Facchini MC, Decesari S, Fuzzi S, Gehrig R, Hüglin C, Laj P, Lorbeer G, Maenhaut W, Mihalopoulos N, Müller K, Querol X, Rodriguez S, Schneider J, Spindler G, ten Brink H, Tørseth K, Wiedensohler A. 2004. A European aerosol phenomenology. 2: Chemical characteristics of particulate matter at kerbside, urban, rural and background sites in Europe. Atmos. Environ. 38: 2579-2595.

Putaud J-P, Van Dingenen R, Alastuey A, Bauer H, Birmili W, Cyrys J, Flentje H, Fuzzi S, Gehrig R, Hansson HC, Harrison RM, Herrmann H, Hitzenberger R, Hüglin C, Jones AM, Kasper-Giebl A, Kiss G, Kousa A, Kuhlbusch TAJ, Löschau G, Maenhaut W, Molnar A, Moreno T, Pekkanen J, Perrino C, Pitz M, Puxbaum H, Querol X, Rodriguez S, Salma I, Schwarz J, Smolik J, Schneider J, Spindler G, ten Brink H, Tursic J, Viana M, Wiedensohler A, Raes F. 2010. A European aerosol phenomenology. 3: Physical and chemical characteristics of particulate matter from 60 rural, urban, and kerbside sites across Europe. Atmos. Environ. 44: 1308-1320.

Raes F, Van Dingenen R, Vignati E, Wilson J, Putaud J-P, Seinfeld JH, Adams P. 2000. Formation and cycling of aerosols in the global troposphere. Atmos. Environ. 34: 4215-4240.

Ramanathan V, Crutzen PJ, Kiehl JT, Rosenfeld D. 2001. Aerosols, climate, and the hydrological cycle. Science 294: 2119-2124.

Ristovski ZD, Suni T, Kulmala M, Boy M, Meyer NK, Duplissy J, Turnipseed A, Morawska L, Baltensperger U. 2010. The role of sulphates and organic vapours in growth of newly formed particles in a eucalypt forest. Atmos. Chem. Phys. 10: 2919-2926.

Roberts GC, Nenes A. 2005. A continuous-flow streamwise thermalgradient CCN chamber for atmospheric measurements. Aerosol Sci. Technol. 39: 206-221.

Rose D, Nowak A, Achtert P, Wiedensohler A, Hu M, Shao M, Zhang Y, Andreae MO, Pöschl U. 2008. Cloud condensation nuclei in polluted air and biomass burning smoke near the mega-city Guangzhou, China. Part 1: Size-resolved measurements and implications for the modeling of aerosol particle hygroscopicity and CCN activity. Atmos. Chem. Phys. Discuss. 8: 17343-17392.

Rudich Y, Donahue NM, Mentel TF. 2007. Aging of organic aerosol: Bridging the gap between laboratory and field studies. Ann. Rev. Phys. Chem. 58: 321-352.

Russell A, Vaughan G, Norton EG. 2010. Large-scale potential vorticity anomalies and deep convection. Submitted to Q. J. R. Meteorol. Soc. (submitted)

Schlesinger WH. 1997. Biogeochemisty: An analysis of global change. $2^{\text {nd }}$ edition. Academic Press: San Diego.

Seguin AM, Norman A-L, Eaton A, Wadleigh M, Sharma S. 2010. Elevated biogenic sulphur dioxide concentrations over the North Atlantic. Atmos. Environ. 44: 1139-1144.

Seinfeld JH, Pandis SN. 1998. Atmospheric Chemistry and Physics: From air pollution to climate change. Pp 724-727. John Wiley: New York.
Slowik JG, Stroud C, Bottenheim JW, Brickell PC, Chang RY-W, Liggio J, Makar PA, Martin RV, Moran MD, Shantz NC, Sjostedt SJ, van Donkelaar A, Vlasenko A, Wiebe HA, Xia AG, Zhang J, Leaitch WR, Abbatt JPD. 2010. Characterization of a large biogenic secondary organic aerosol event from eastern Canadian forests. Atmos. Chem. Phys. 10: 2825-2845.

Smith JN, Moore KF, Eisele FL, Voisin D, Ghimire AK, Sakurai H, McMurry PH. 2005. Chemical composition of atmospheric nanoparticles during nucleation events in Atlanta. J. Geophys. Res. 110: D22S03, DOI: 10.1029/2005JD005912.

Sorjamaa R, Laaksonen A. 2006. The influence of surfactant properties on critical supersaturations of cloud condensation nuclei. J. Aerosol Sci. 37: $1730-1736$.

Sorjamaa R, Svenningsson B, Raatikainen T, Henning S, Bilde M, Laaksonen A. 2004. The role of surfactants in Köhler theory reconsidered. Atmos. Chem. Phys. 4: 2107-2117.

Spracklen DV, Carslaw KS, Kulmala M, Kerminen V-M, Mann GW, Sihto S-L. 2006. The contribution of boundary layer nucleation events to total particles concentrations on regional and global scales. Atmos. Chem. Phys. 6: 5631-5648.

Swietlicki E, Zhou J, Berg OH, Martinsson BG, Frank G, Cederfelt SI, Dusek U, Berner A, Birmili W, Wiedensohler A, Yuskiewicz B, Bower KN. 1999. A closure study of sub-micrometer aerosol particle hygroscopic behaviour. Atmos. Res. 50: 205-240.

Swietlicki E, Hansson H-C, Hämeri K, Svenningsson B, Maßling A, McFiggans GB, McMurry PH, Petäjä T, Tunved P, Gysel M, Topping DO, Weingartner E, Baltensperger U, Rissler J, Wiedensohler A, Kulmala M. 2008. Hygroscopic properties of submicrometer atmospheric aerosol particles measured with $\mathrm{H}$ TDMA instruments in various environments: A review. Tellus 60B 432-469.

Topping DO, McFiggans GB, Coe H. 2005a. A curved multicomponent aerosol hygroscopicity model framework. Part 1: Inorganic compounds. Atmos. Chem. Phys. 5: 1205-1222.

Topping DO, McFiggans GB, Coe H. 2005b. A curved multi-component aerosol hygroscopicity model framework. Part 2: Including organic compounds. Atmos. Chem. Phys. 5: 1223-1242.

Topping DO, McFiggans GB, Kiss G, Varga Z, Facchini MC, Decesari S, Mircea M. 2007. Surface tensions of multi-component mixed inorganic/organic aqueous systems of atmospheric significance: Measurements, model predictions and importance for cloud activation predictions. Atmos. Chem. Phys. 7: 2371-2398.

Ulbrich IM, Canagaratna MR, Zhang Q, Worsnop DR, Jimenez JL. 2009. Interpretation of organic components from positive matrix factorization of aerosol mass spectrometric data. Atmos. Chem. Phys. 9: $2891-2918$.

Väkevä M, Kulmala M, Stratmann F, Hämeri K. 2002. Field measurements of hygroscopic properties and state of mixing of nucleation mode particles. Atmos. Chem. Phys. 2: 55-66.

Vögtlin R, Koßmann M, Gusten H, Heinrich G, Fiedler F, Corsmeier U, Kalthoff N. 1996. Transport of trace gases from the Upper Rhine valley to a mountain site in the northern Black Forest. Phys. Chem. Earth 21: $425-428$.

Weingartner E, Burtscher H, Baltensperger U. 1997. Hygroscopic properties of carbon and diesel soot particles. Atmos. Environ. 31: 2311-2327.

Whiteman CD, McKee TB. 1978. Air pollution implications of inversion descent in mountain valleys. Atmos. Environ. 12: 2151-2158.

Williams PI, McFiggans GB, Gallagher MW. 2007. Latitudinal aerosol size distribution variation in the eastern Atlantic Ocean measured aboard the FS-Polarstern. Atmos. Chem. Phys. 7: 2563-2573.

Wulfmeyer V, Behrendt A, Bauer H-S, Kottmeier C, Corsmeier U, Blyth A, Craig G, Schumann U, Hagen M, Crewell S, Di Girolamo P, Flamant C, Miller M, Montani A, Mobbs SD, Richard E, Rotach MW, Arpagaus M, Russchenberg H, Schlüssel P, König M, Gärtner V, Steinacker R, Dorninger M, Turner DD, Weckwerth T, Hense A, Simmer C. 2008. The Convective and Orographically induced Precipitation Study: A research and development project of the World Weather Research Program for improving quantitative precipitation forecasting in low-mountain regions. Bull. Am. Meteorol. Soc. 89: $1477-1486$.

Zhang Q, Stanier CO, Canagaratna MR, Jayne JT, Worsnop DR, Pandis SN, Jimenez JL. 2004. Insights into the chemistry of new particle formation and growth events in Pittsburgh based on aerosol mass spectrometry. Environ. Sci. Technol. 38: 4797-4809.

Zhang Q, Jimenez JL, Canagaratna MR, Allan JD, Coe H, Ulbrich I, Alfarra MR, Takami A, Middlebrook AM, Sun YL, Dzepina K, Dunlea E, Docherty K, DeCarlo PF, Salcedo D, Onasch T, Jayne JT, Miyoshi T, Shimono A, Hatakeyama S, Takegawa N, Kondo Y, Schneider J, Drewnick F, Borrmann S, Weimer S, Demerjian K, 
Williams PI, Bower K, Bahreini R, Cottrell L, Griffin RJ, Rautiainen J, Sun JY, Zhang YM, Worsnop DR. 2007. Ubiquity and dominance of oxygenated species in organic aerosols in anthropogenicallyinfluenced Northern Hemisphere midlatitudes. Geophys. Res. Lett. 34: L13801, DOI: 10.1029/2007GL029979.
Zhou J, Swietlicki E, Hansson HC, Artaxo P. 2002. Submicrometer aerosol particle size distribution and hygroscopic growth measured in the Amazon rain forest during the wet season. J. Geophys. Res. 107: 8055, DOI: 10.1029/2000JD000203. 